Population Series

No. 88-7, August 1997

Population and the Asian Economic Miracle

\title{
Saving, Wealth, and the Demographic Transition in East Asia
}

Ronald Lee, Andrew Mason, and Timothy Miller
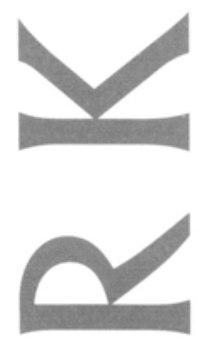

EAST-WEST CENTER 
The U.S. Congress established the East-West Center in 1960 to foster mutual understanding and cooperation among the governments and peoples of the Asia Pacific region including the United States. Funding for the Center comes from the U.S. government with additional support provided by private agencies, individuals, corporations, and Asian and Pacific governments.

East-West Center Working Papers are circulated for comment and to inform interested colleagues about work in progress at the Center.

For more information about the Center or to order publications, contact:

Publication Sales Office

East-West Center

1601 East-West Road

Honolulu, Hawaii 96848-1601

Telephone: 808-944-7145

Facsimile: 808-944-7376

Email: ewcbooks@EastWestCenter.org

Website: www.EastWestCenter.org 


\title{
Saving, Wealth, and the Demographic Transition in East Asia
}

\author{
Ronald Lee, Andrew Mason, and Timothy Miller
}

Ronald Lee is a Professor of economics and demography in the Department of Demography at the University of California at Berkeley. Andrew Mason is a Senior Fellow with the East-West Center's Program on Population. Timothy Miller is in the Department of Demography at the University of California at Berkeley.

East-West Center Working Papers: Population Series are an unreviewed and unedited prepublication series reporting on research in progress. Please direct orders and requests to the East-West Center's Publication Sales Office. Single copies are available at no charge by surface post while supplies last. Charges for additional copies are $\$ 1.00$ each. Charges for airmail delivery are $\$ 1.50$ each within the United States and its territories and $\$ 4.00$ each elsewhere.

Established in 1969 as a unit of the East-West Center, the Program on Population conducts research and offers professional education focusing on population issues, with emphasis on the analysis of demographic and human-resource trends, their social and economic causes and consequences, and their policy implications in Asia, the Pacific, and the United States.

Support for the Program on Population's project on Population and the Asian Economic Miracle is provided by the United States Agency for International Development (USAID), the Rockefeller Foundation, the William and Flora Hewlett Foundation, and the Ministry of Foreign Affairs (MOFA) of Japan. The University Research Center of Nihon University (Japan) is a collaborating institution. Support from USAID and MOFA is provided as part of the Common Agenda for Cooperation in Global Perspectives.

For more information, contact Andrew Mason, Principle Investigator, East-West Center Program on Population. 

August 11, 1997

Preliminary Draft

\title{
Saving, Wealth, and the Demographic Transition in East Asia
}

\author{
Ronald Lee \\ Demography and Economics \\ University of California \\ 2232 Piedmont Ave \\ Berkeley, CA 94720 \\ E-mail: rlee@demog.berkeley.edu \\ Andrew Mason \\ Department of Economics \\ University of Hawaii at Manoa, and \\ Program on Population \\ East-West Center \\ E-mail: amason@hawaii.edu \\ Timothy Miller \\ Demography \\ University of California \\ 2232 Piedmont Ave \\ Berkeley, CA 94720 \\ E-mail: tmiller@demog.berkeley.edu
}

The authors gratefully acknowledge helpful comments on an earlier draft from John Bauer and Matthew Higgins and help with data issues from Frank Harrigan, Tsung Li-Hom, and Huang Fung-Mey. They also acknowledge the assistance of Jeff Brown and Noreen Tanouye at the Program on Population of the East-West Center and Mike Clune in Demography at Berkeley. Lee and Miller's research for this paper was funded by NIA grant AG11761. Support for this paper was also provided by the Agency for International Development, the Rockefeller Foundation, the William and Flora Hewlett Foundation, and the Ministry of Foreign Affairs of Japan. 


\section{Abstract}

This paper assesses the extent to which demographic forces can explain the substantial increases in national saving rates in East Asia over the last few decades, under the strong assumption that saving is motivated by a desire to provide for consumption in retirement. Comparative, steady-state analysis shows that relatively low rates of saving should characterize either pre- or post-transition societies, but that post-transition societies have a much higher demand for wealth than do societies yet to have begun their demographic transition. A dynamic simulation model is used to analyze saving rates during the transition. Using detailed demographic and economic data based on the experience of Taiwan, we show that demographic factors may underlie a substantial portion of the rise in net national saving experienced in the region. Further, our model anticipates a rapid decline in saving as countries approach the end of their demographic transitions and achieve high levels of wealth. 


\section{Introduction}

\section{Population and Economic Development}

In 1958, Coale and Hoover published an influential analysis of population and economic development, arguing that growth in per capita income would be strongly accelerated by an earlier fertility decline in Third World countries, and particularly in India, their case study. At the center of their analysis was the hypothesis that higher fertility, and the resulting higher proportion of children in the population, would depress aggregate savings rates and thereby slow the growth of capital. Controversial empirical work by Leff (1969) (discussed below) supported this hypothesis about savings, and the Coale-Hoover conclusions were widely accepted and had an important influence on public policy for two or three decades.

In the mid-1980s, there were a number of revisionist syntheses of the research literature, arguing that there was no clear evidence that demography influenced savings rates, or that capital accumulation was the key factor in economic development (see World Bank, 1984; National Research Council, 1986; Kelley, 1988, for example). In a Solow growth model, wide variations in the population growth rate have no impact on the rate of per capita income growth and a modest impact on the level of per capita income. Exercises in growth accounting typically accorded capital a small role in explaining differences in economic growth rates. This revisionist literature typically accorded population growth and age distribution only a small role in hampering or encouraging development.

More recently, a post-revisionist literature has begun to emerge. Many studies now report negative associations of population growth rates and per capita income growth rates in international cross sections, associations that were previously found to be negligible or insignificant. Recent literature finds larger effects of savings rates and population growth rates once human capital formation is included in models in addition to physical capital (Mankiw, Romer and Weil, 1994). The phenomenal economic growth rates in East Asia have also now been found, by some, to be almost entirely due to factor accumulation, with physical capital accumulation playing by far the dominant role. Research on the life cycle saving hypothesis by Mason $(1986,1987)$ explains why demography has appeared to have ambiguous effects in the past, and finds an important role for demography with an improved specification. His work has been supported by other empirical studies (Kelley and Schmidt, 1996). Williamson and Higgins (1997) find that the early and rapid demographic transition in East Asia accounts for much of the high savings rates and negative foreign capital flows in recent decades, and suggest that the same may occur throughout the Third World. They conclude: "Coale and Hoover were right!"

This new literature suggests that demographic factors may strongly influence the pace of economic development, through savings and capital accumulation, rather as Coale and Hoover had initially suggested. However, although the life cycle saving hypothesis is frequently invoked to motivate empirical studies of demography and savings, very little work has been done to model the relation of actual demographic change to savings rates under the life cycle saving hypothesis; indeed, the early work of Tobin (1967) may still represent the leading effort to incorporate and simulate the effects of realistic demography on individual and aggregate savings. (Here we need to check contributions by Auerbach and Kotlikoff, and by Attanasio; we have not surveyed the more recent literature.) Tobin's analysis, however, was comparative static, and based on US demography of the $1960 \mathrm{~s}$, so it is of very limited relevance for Third World demographic transitions.

In this paper, we extend the basic modeling strategy set out by Tobin, and use it to examine the effects of different demographic regimes, drawn from Taiwanese experience, on life cycle and aggregate saving. We first consider comparative static results. We then carry out dynamic simulations, exploring the effects 
of Taiwan's transition, while taking interest rates and productivity growth rates as exogenous. In a third part, not yet carried out, we will use fitted production functions to endogenize interest rates and productivity. We have also attempted to take some account of the familial system of old age support in our comparative static analysis, but not yet in our dynamic analysis. It appears that under the assumption of life cycle savings, and with plausible values for the key parameters, the demographic transition in Taiwan could indeed explain a portion of the remarkable rise in savings rates and capital accumulation in Taiwan since 1950.

\section{Demographic change}

In the classic demographic transition, starting from high levels of fertility and mortality, mortality begins to decline first, leading to accelerating population growth rates and increasing proportions of children in the population. Eventually fertility also begins to decline, leading to slowing population growth and declining proportions of children. Numbers of elderly grow rapidly, however, in part because of increasing survival rates, and in part because they spring from cohorts born during the period in which population growth was rapid, and each generation was larger than the preceding. Eventually fertility stabilizes at some relatively low level, perhaps below replacement, while mortality continues to decline, so far without limit. Population aging continues, reaching levels not yet experienced at the national level.

This stylized portrait of the demographic transition is illustrated by Figure 1, based on the experience of India, which has had a far slower transition than the countries of East Asia, but which is nonetheless a useful example. While Feeney and Mason (1997) find that East Asian populations moved through the fertility transition in 25 to 30 years, in the Indian simulation the fertility decline takes twice this long. The figure shows that changes in the age distribution are large but not monotonic, and that following the difficulties of the early stages of the transition, when dependency rates climb, there is a sustained period after fertility decline has begun, when child dependency is low and the proportion of elderly has not yet become substantial. The countries of East Asia have passed through this stage of the demographic transition during the past three or four decades, coincident with their period of rapid growth in per capita income. The question naturally arises whether the early and sharp fertility decline in this area might not account for, or at least has contributed to, the rapid economic progress.

Let us take the case of Taiwan as an example, as we shall through out this paper. As a first approximation to assessing the economic implications of the demographic change, we can calculate the so-called "support ratio" (Cutler et al, 1990). This is a refined version of the dependency ratio, and gives the population weighted by a standard age schedule of labor earning to the ratio of the population weighted by a standard age schedule of consumption. We have calculated the age schedule of consumption based on household expenditure data, where consumption is allocated to individuals within the household based loosely on age specific consumption weights (Deaton and Muellbauer, 1986; Lazear and Michael, 1988), and on the average age schedule of labor earnings. The age schedule of labor earnings is the average for Taiwan from 1976 to 1991, and reflects both male and female earnings and self-employment income. Public expenditures by age of recipient are also included in the age schedules.

Figure 2 shows how this support ratio has changed from 1950 to 1994, and how it is projected to change in the future up to 2100 . Two variants are plotted, representing extreme assumptions about the relative consumption of the young and the old. Between 1950 and 2000, the support ratio rises by between 17 percent and 35 percent, depending on the weights used. This means that the average person could consume 17 to 35 percent more at each age in the year 2000 than in the year 1950, even if there were no change in labor earnings by age, solely because of reductions in the numbers of dependents supported by each working age person. It also means that 17 to 35 percent of labor earnings could be diverted to savings in 2000 , with no reduction in consumption at each age relative to 1950 . Other consequences of 
Figure IA
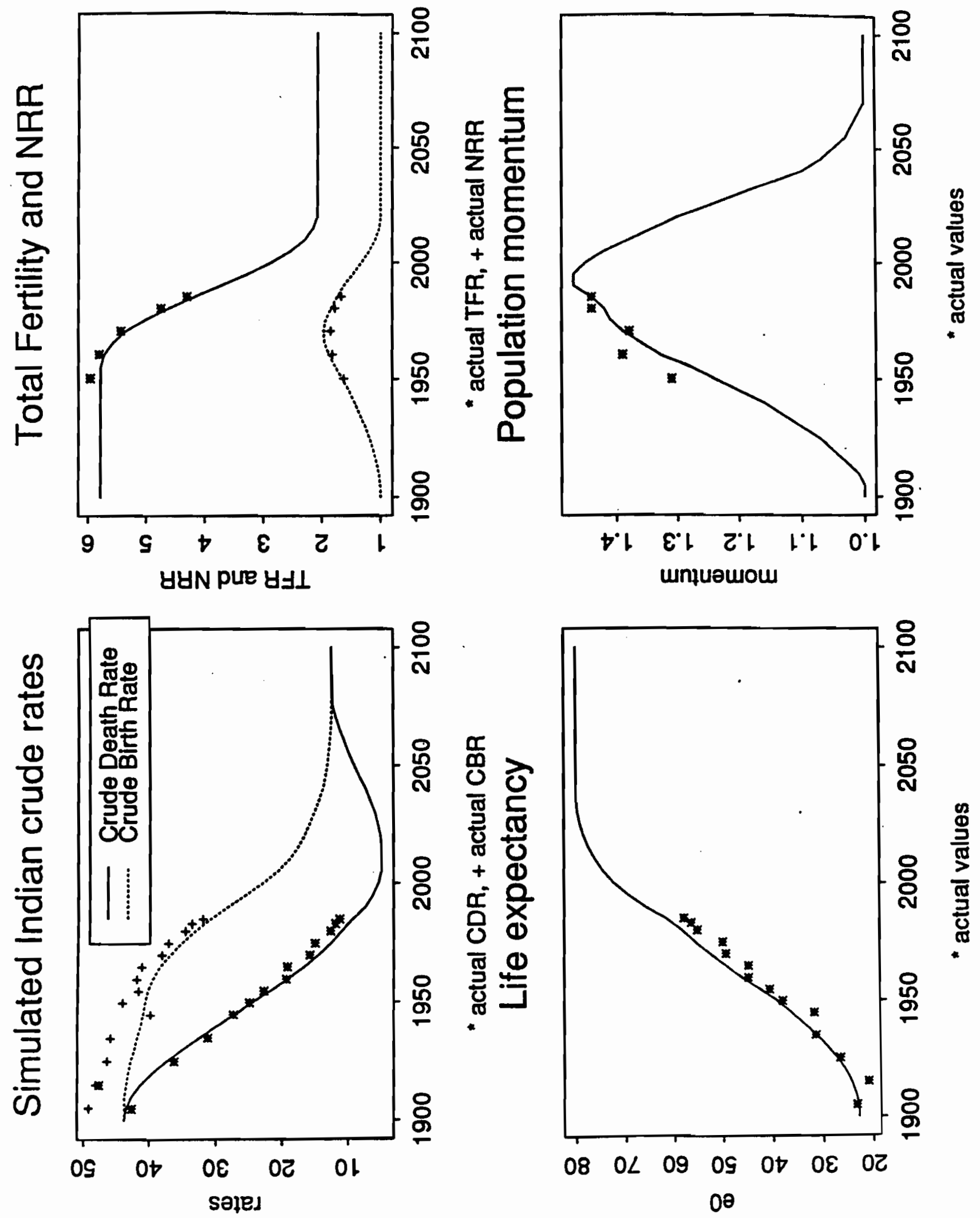
Figure 1B
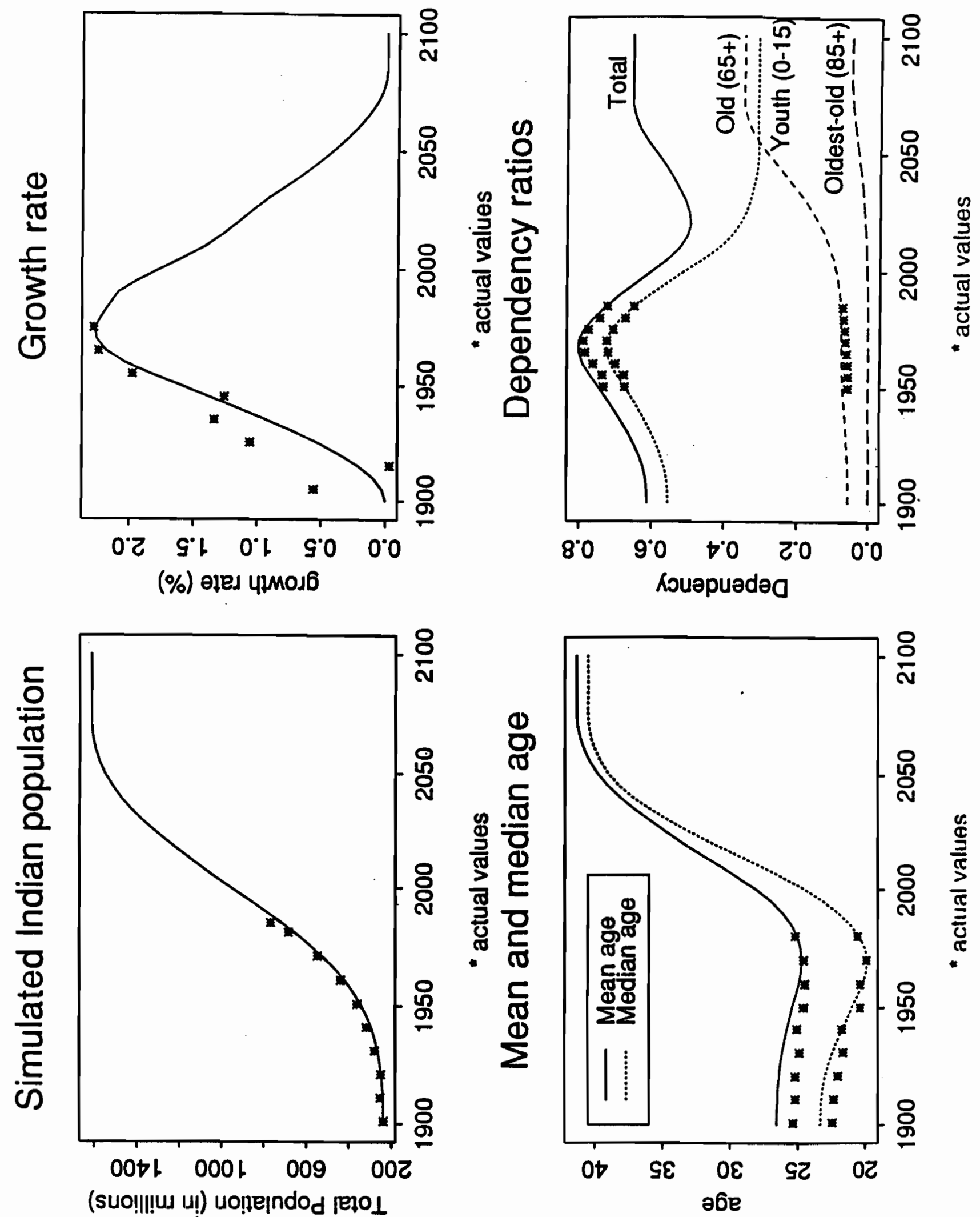


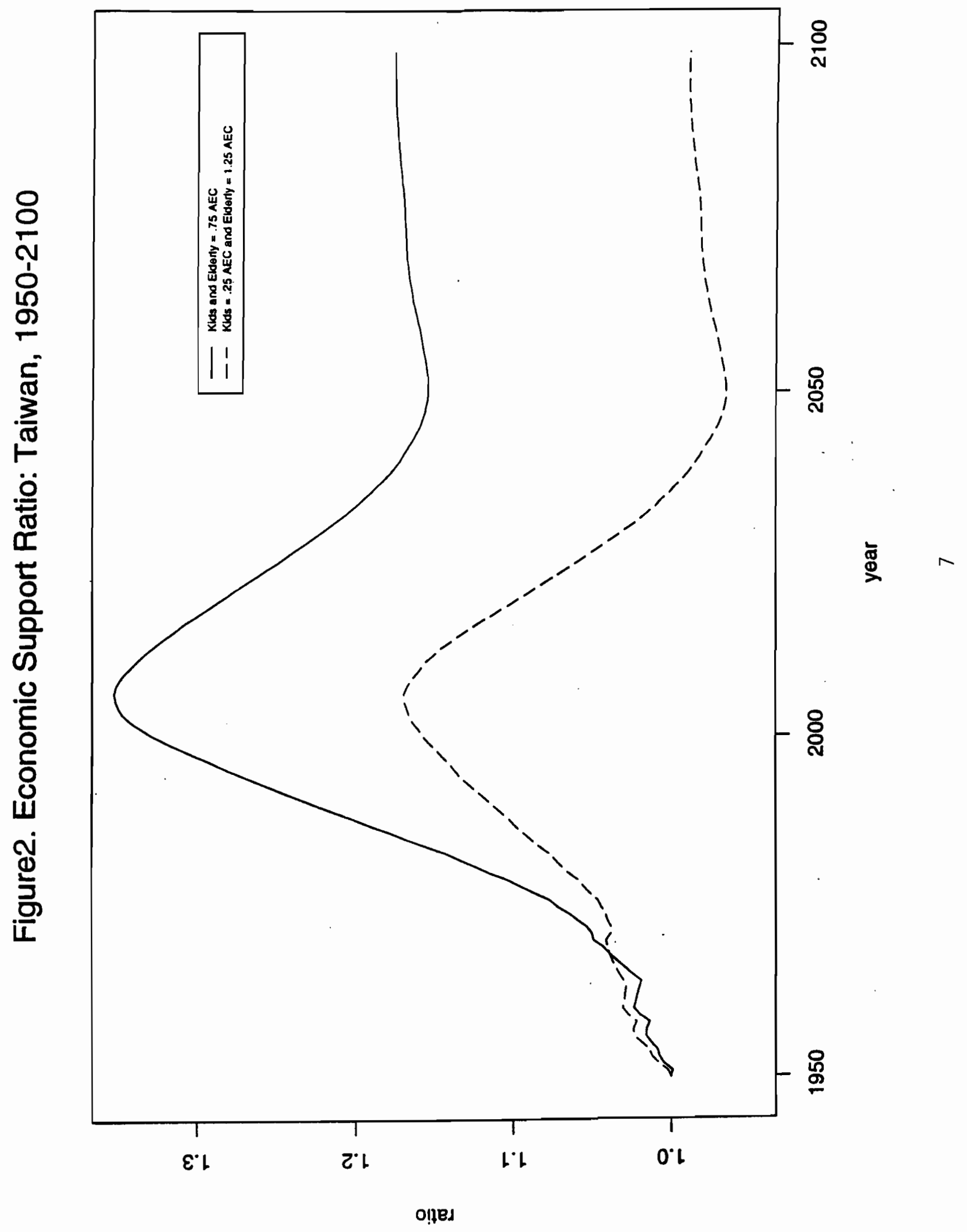


the demographic transition, such as capital deepening and increased labor force participation of women, would reinforce this already substantial effect. Following the year 2000, the support ratio plunges, in one scenario to a level worse than in 1950, and in the other scenario to a level midway between that of 1950 and 2000. This deterioration reflects the onset of population aging.

It is evident from these support ratios that during the initial stages of the demographic transition, the changes in the age distribution are highly favorable, in the sense that if there were no change in age profile of consumption or earning, surplus income would become available for other uses. Such surplus income might be used to increase consumption proportionately at every age; or to increase savings and capital formation; or to increase leisure; or consumption might rise at some ages, but not at others. It is not possible to say what use is made of the surplus, even in theory, without additional information about the institutional context within which income is reallocated from net earners to net consumers across the age distribution. In a society in which full consumption smoothing over the life cycle is implemented through interage transfers, we would expect consumption to rise equi-proportionately at all ages, and we would expect no effect on savings rates. In a society in which children were reared through intra-familial transfers, while the elderly provided for their own retirement through life cycle saving, we would expect that savings rates would rise, but that the consumption of the currently elderly would not benefit at all from the surplus generated by the demographic changes. Only later generations of elderly, who had lived through a regime of lower fertility and expected longer life, would realize higher consumption in old age. If old age is supported by public sector transfers through a PAYGO system, there would again be no obvious effect on savings rates, and the division of the surplus between the working generations and the elderly would be up for political grabs.

For this reason, to observe that dramatic increases in saving and investment were made possible by the demographic transition is not to say that in fact, the transition did account for the increase in savings which occurred. And to observe that the population age distribution will turn strongly disadvantageous in the 21 st century is not to say that reductions in saving rates will therefore result. The consequences of these dramatic demographic changes depend on the motivations and behaviors that are shaped by the institutional context. We will not attempt to address this issue in a general way, but rather will do so through the lens of the life cycle saving model, modified to take account of the family support system.

\section{Background}

Before presenting our model, it is useful to highlight a few salient features of the East Asian experience that bear on the analysis of saving, population, and economic growth presented below.

\section{High rates of saving, but not always}

High saving rates is arguably the feature that most distinguishes the economies of East Asia from the rest of the world. In the early 1990s, saving as a percentage of GDP averaged 35 percent among the countries of Northeast Asia and 33 percent in Southeast Asia (Williamson and Higgins, 1997). By contrast, saving as a percentage of GDP averaged just under 10 percent in South Asia, 16 percent in Sub-Saharan Africa, 20 percent in Latin America, and 21 percent among OECD countries (World Bank, 1995).

Saving rates have not always been so high. In South Korea, for example, saving rates were barely positive in the aftermath of the Korean war and were sufficiently low during the 1960s and early 1970s that one well-known study of saving asked "Why do Koreans save so little?" (Williamson, 1979). More generally saving rates have exhibited a steady upward trend during the last four decades transforming the region from one with unexceptional saving rates and a substantial dependence on foreign capital to one 
which is funding not only its own substantial domestic investment needs but those of many other countries as well.

Thus, any successful analysis of East Asian saving rates must provide plausible explanations of both the upward trend in saving and the atypically high rates of saving that persist today.

\section{Rapid economic growth}

By any measure of economic growth, the economies of East Asia have excelled during the past three decades. Between 1960 and 1990, the six countries highlighted in this conference averaged an annual increase in real gross domestic product per capita of 5.5 percent and in real gross domestic product per worker of 5.0 percent (Summers and Heston, 1991). The high performance feature of these economies is important for two reasons. First, the high rate of economic growth is, by many accounts, one of the important factors behind East Asia's high rate of saving.

Second, current wisdom is that the high rates of saving (or investment) account for more of the region's economic growth than any other single factor. In some studies, capital accumulation accounts for more East Asian economic growth than all other factors combined. Under these circumstances, understanding the reasons behind East Asian saving rates is all the more important. Given the mutually causal nature of saving and growth, explaining saving rates is all the more difficult.

\section{Declining youth dependency and extended life expectancy}

The populations of East Asia have experienced two important changes with potential implications for aggregate saving. The first is the decline in youth dependency. With the exception of Indonesia, the average number of children under 15 per household dropped by half or more between 1960 and 1990 . As of 1990, childrearing households at all ages averaged two or fewer children under the age of 19, again, in all but Indonesia. Because saving by post-childrearing households may be influenced by the number of children they reared, it is important to understand that, on average, they have more than two surviving offspring. Men and women at older ages average as many as four to five surviving offspring depending on the age and the country.

The second demographic change is the dramatic rise in life expectancy. In Taiwan, for example, life expectancy at birth increased from 53.1 in 1950 to 71.8 in 1991 for males and from 55.7 to 77.2 for females over the same period. Of greater relevance to saving behavior are changes at older ages. Between 1950 and 1991, expectation of life at age 60 increased by $45 \%$ for men (from 12.69 years to 18.36 years) for men and by $32 \%$ for women (from 15.73 years to 20.80 years) (Taiwan, 1993.) These changing expectations of life in retirement have been omitted from many analyses of life cycle saving.

\section{Sources of growth}

It is generally agreed that rapid growth of three factors of production, physical capital, human capital, and labor, played a direct and instrumental role in the rapid growth of GDP in East Asia. Likewise, growth in output per worker is in large part a consequence of capital deepening, i.e., increases in physical and human capital per worker.

Most recent studies have discounted the importance of "technological innovation" or growth in total factor productivity. There is disagreement over just how much total factor productivity (TFP) has grown, but the available evidence supports the view that TFP growth has been slower for the NIEs than for the G-5 countries (France, West Germany, Japan, the UK, and the US). Economic growth models typically 
assume that technological progress is labor augmenting (Mankiw et al., 1992, for example); however, some empirical work supports alternative forms of technological progress (Kim and Lau (1995), for example, finds that technological progress is physical and human capital augmenting).

There is active debate regarding the relative importance of physical and human capital. A resolution of this issue is hindered, in part, by difficulties in measuring capital. Measuring human capital is particularly difficult and there are no widely accepted measures. However, there is no question but that the share of output devoted to physical capital has been far greater than the share devoted to human capital. Likewise, the rate of growth of physical capital has under any reasonable assumption been greater than the rate of growth of human capital. Most empirical studies of East Asia find that the accumulation of physical capital has contributed far more to economic growth than has the accumulation of human capital.

That said, there is still substantial disagreement about the importance of physical capital. Kim and Lau argue that the elasticity of output with respect to physical capital is substantially greater in the NIEs than in G-5 countries. Taking 1970 as a point of reference, their estimates for G-5 countries vary from 0.216 (US) to 0.322 (Japan). For the NIEs, their estimates vary from 0.488 (Hong Kong) to 0.531 (Taiwan). Mankiw et al do not explicitly consider the issue, but their estimate for OECD countries (0.14) is about half their estimate using a combined sample of OECD and non-OECD countries ( 0.29 or 0.31 depending on the sample). If high elasticity estimates for capital are correct, then saving will have a more substantial impact on growth which may, in turn, lead to higher rates of saving.

The existence of scale economies is also an important issue. The traditional view, and one that has been supported in many empirical studies, is that constant returns to scale prevail. However, one might anticipate that small economies, e.g., Taiwan or South Korea, would exhibit increasing returns to scale. Research by Kim and Lau, 1995 finds that the NIEs exhibited increasing returns to scale during the last three decades, but that the scale elasticity has declined over time and is approaching one. They also find that Japan exhibited increasing returns to scale until the early $1970 \mathrm{~s}$, but now is characterized by decreasing returns to scale.

\section{Savings Rates and Dependency-A Literature Review}

Aggregate saving in East Asia has two prominent features that any comprehensive model of saving must explain. First, the rates of saving among East Asian countries are consistently higher than elsewhere in either the industrialized or the developing world. This is not only true of Taiwan, but of other rapidly growing East Asian economies.

Second, saving rates have increased very substantially during the post-World War II era. The exact timing has varied among the countries with Japanese saving rates rising relatively early and saving rates in other economies rising somewhat later, but the upward trend is an unmistakable and important feature of national rates of saving in East Asia. Given the high rates of saving that prevail in many of these economies, further increases would appear to be unlikely. Indeed, some evidence of decline is already apparent especially in the case of Japan.

Research on saving and development has investigated a variety of hypotheses that might account for these and other features of East Asian saving. Major hypotheses are briefly reviewed below including: 1) measurement issues, 2) the level of income, 3) government and foreign saving, 4) the rate of economic growth, and 5) demographic factors. The latter two are particularly relevant to this paper and are treated in greater detail. 


\section{Measurement issues}

International differences or trends in saving may be accounted for, in part, by measurement. The reliability of estimates varies enormously from country to country and over time. The capabilities and resources of statistical agencies vary greatly from country to country as do the circumstances under which data are collected. As economies become increasingly monetized, the collection of reliable economic data is eased, though still difficult. The low rates of saving reported for many low-income countries might reflect, in part, the difficulty of estimating saving when agriculture and small-scale family enterprise dominate the economic structure. Some portion of the secular increase in national saving in East Asia may reflect improved measurement; likewise, some of the reported gap in saving between the economies of East Asia and those of less developed countries may be a by-product of measurement problems.

Variation in the methodologies employed to construct national income accounts, particularly differences between the US and Japan, have been the subject of careful scrutiny. Horioka (1993), Dekle and Summers (1991), Hayashi (1986) and others differ in their assessments, but most conclude that even after adjusting for differences between Japanese methods and those followed in the US, Japan's rate of saving has still been high by international standards.

\section{Government and Foreign Saving}

Most saving models are models of household behavior. However, national saving is, in an accounting sense, determined by government saving, not just private saving. ${ }^{\prime}$ Overlapping generation models provide a theoretical rationale for treating national saving, including government saving, as the outcome of household decision-making. If Ricardian equivalence holds, households substitute private saving for government saving dollar per dollar. Hence, national saving would be entirely independent of government saving and governed solely by household behavior. Empirical studies almost uniformly reject Ricardian equivalence; however, they do find some substitution between private and public saving. Estimates of 25 cents per dollar are fairly typical, but range as high as 50 cents per dollar. Hence, high rates of saving could, in principle, be explained by high rates of government saving (Schmidt-Hebbel, et al., 1996). ${ }^{2}$

By and large East Asian governments have been fiscally prudent. Government saving has contributed to high rates of national saving, but is not primarily responsible. Taiwan is a case in point. Government saving has been fairly substantial and consistently positive. In the early 1950 s, public and private saving were about equally important, but since that time the upward trend in saving has been driven primarily by the steady rise in private saving.

\footnotetext{
${ }^{1}$ Although in some instances research on saving ascribes independent roles to "household" and "corporate" saving, the theoretical rationale for doing so is poorly articulated. Given that corporations are owned by households and that the accumulation of wealth by corporations is directly reflected in the balance sheets of owners, the standard convention is to treat private saving, the net of household and corporate saving, as the outcome of household decision-making.

${ }^{2}$ This leaves open the question of why some governments run surpluses and others run deficits. Although government saving is often treated as an exogenous, policy variable, this obviously overstates the independent control that governments exercise over spending and taxing. Undoubtedly, some of the forces that drive private saving influence public saving, as well.
} 
Singapore is a special case because of the activist role the government has played in managing household saving. By government mandate, workers and employers each contribute $20 \%$ of earnings to the government operated pension program. Until recently, these funds could neither be withdrawn nor used as collateral. In the last few years, these provisions have been relaxed to some extent. A prescribed portion of funds can now be withdrawn as a down payment on a residence. In addition, individuals are allowed to borrow from their account in order to finance the education of family members. In any event, the high rate of saving by households in Singapore is to a very substantial extent mandated rather than a reflection of household decision-making. Arguably, saving rates are high in Singapore as a matter of policy and age-structure, rather than as a matter of choice.

The impact of foreign saving on domestic saving has also frequently been considered in the developing country context. The thesis is that foreign saving will drive out domestic saving, for example, by driving down domestic rates of return. Capital flows into Taiwan and South Korea were very substantial during the post-World War II period. If foreign saving does drive out domestic saving, the secular trend in saving in those two countries could be explained in part by the declining dependence on foreign capital. However, most of the empirical work on this issue provides little support for the view that domestic saving is depressed by foreign saving (Schmidt-Hebbel et al., 1996).

\section{Financial repression, financial reform, interest rates, etc.}

The development of efficient financial institutions free from government interference is often cited as one of the principle causes of both an increase in national saving and a more efficient use of the investment capital that is available (Shaw, 1973; McKinnon, 1973). The East Asian experience is not entirely supportive of the view that financial repression depresses household saving. High saving rates and financial repression comfortably co-existed in Japan, South Korea, and Taiwan for many years (Harrigan, 1996).

The more general literature on interest rates and saving in developing countries provides little evidence that interest rates have a substantial positive impact on national saving. Fry and Mason (1982), and Fry (1978) present evidence from developing countries for a positive interest elasticity. However, studies by Giovannini (1985), Gupta (1984, 1987), Edwards (1995) and Masson et al. (1995) conclude that real interest rates do not have a significant impact on saving rates. In this regard, Japan's experience is instructive - throughout the 1960s high saving rates accompanied real rates of interest that were by many measures negative.

\section{The Level of income}

The often-observed rise in saving that accompanies economic development is sometimes attributed to the impact of the level of per capita income, per se, on household saving. The two models most frequently used to explain household saving, the life cycle model and the permanent income model, imply that saving rates are independent of expected income. However, unanticipated increases in income in either model will yield higher rates of saving. Economists have also maintained that at low enough levels of income, consumers may have a very high rate of time preference and are unwilling to postpone current consumption. Only as standards of living improve beyond basic subsistence will consumers begin to save. The lack of saving by all but high-income groups in consumer expenditure surveys conducted in developing countries lends credence to this view. The high correlation between income and consumption over the life cycle provides further evidence in support of an income effect (Deaton $(1989,1991)$ and Carroll and Summers (1991)). 


\section{The Rate of growth}

A positive correlation between saving and the rate of growth of per capita or total income is one of the persistent statistical regularities found in the saving and development literature. That the rate of income growth will lead to higher rates of saving is an implication of either the permanent income hypothesis or the life-cycle income hypothesis. The permanent income hypothesis posits that the marginal propensity to save out of transitory income is higher than out of permanent income. Thus, to the extent that rapid increases in income are unanticipated, higher rates of saving will result (Friedman, 1957). Higher rates of income growth can also yield higher rates of saving in the life-cycle model. If household saving is dominated by the pension motive, aggregate saving will be higher if the distribution of income across generations favors young (saving) households. Because younger generations have relatively higher lifetime incomes in rapidly growing economies, aggregate saving will be higher (Modigliani, 1966, 1988; Modigliani and Brumberg, 1954). This will be more likely to be true if interest rates rise with productivity growth rates, and the elasticity of intertemporal substitution for consumption is not small; otherwise, the young generations with expectations of much higher future earnings, may dissave strongly in order to consume in the present, reducing aggregate saving rates. A positive rate of growth effect is also more likely when the nature of the growth in earnings is such that the shape of the earnings profile for cohorts is not altered.

The rate of growth effect could lead to a virtuous circle whereby higher saving leads to higher investment and higher economic growth leading to even higher saving and so on. In the absence of further elaboration, however, it leaves unanswered the question of why the countries of East Asia became members of the virtuous circle and other countries did not. Hence, it provides an incomplete explanation of why East Asian countries have higher rates of saving.

The simple rate of growth model can not, without modification, account for the secular trend in saving in East Asia (Collins, 1991; Kang, 1994). Saving in South Korea or Taiwan are cases in point. Rates of economic growth have been consistently high for the last three decades with no tendency towards increase. Two possible explanations can be offered for why the impact of the rate of growth would have increased over time. One explanation is that the appropriate measure of income growth is not growth during the current period, but growth over a long time period. Changes in the actual intergenerational distributions of income are the by-product of long-run changes in the rate of economic growth. Likewise, the long-run expectations about the rate of growth, which may determine saving, may respond slowly to actual changes in growth.

The variable rate-of-growth saving model offers a second explanation of the rise in saving. The impact of the rate of growth of income in the life cycle model depends on the timing of consumption relative to earning. The greater the lag between earning and consuming, the greater the impact of an increase in the rate of growth of income (Mason, 1981; Fry and Mason, 1983; Mason, 1987, 1988). ${ }^{3}$ In the simple rate of growth model, the timing of consumption relative to earning is taken as given, but demographic factors, interest rates, and other factors affect the timing and, in turn, aggregate saving. In a high growth economy, changes in variables that affect the timing have a magnified effect. Hence, the current high rates of saving and the strong secular trend in saving can be explained, in principle, by a high rate of

\footnotetext{
${ }^{3}$ If rapid productivity growth tilts age-earnings profiles upwards for each generation, so that the average age of earning is later in the life cycle than when growth is slower, then the lag between earning and consuming may diminish or reverse, in which case the rate of growth effect may turn negative.
} 
economic growth working in conjunction with a shift in the timing of consumption and earning. We will discuss these ideas in the context of demographic change below.

\section{Demographic factors}

Interest in the impact of demographic factors on aggregate savings owes its beginnings to Coale and Hoover's study of India (Coale and Hoover, 1958), Tobin's simulation model which considers the impact on household consumption of variation in the number of equivalent adults (Tobin, 1967), Leff's crossnational empirical study of the impact of youth and old-age dependency ratios on national saving rates (Leff, 1969), and life-cycle model research by Modigliani and his colleagues (Modigliani, 1966, 1988; Modigliani and Brumberg, 1954). The recurring theme in this literature, crudely stated, is that populations with large dependent populations will save less. If this is true, saving rates will rise during the early phases of the demographic transition as the relative numbers of young dependents decline. In later stages, saving rates will decline as the relative number of elderly dependents increases. (Williamson and Higgins identify an additional phase of rising youth dependency which would depress saving rates in the earliest stages of the demographic transition.)

Empirical studies of the impact of dependency on aggregate saving have yielded mixed results. In his original study and in several replications, Leff $(1969,1980,1984)$ finds evidence from international cross-section data that supports the simple dependency hypothesis. His results have been challenged with some effectiveness by a number of critics (Adams, 1971; Bilsborrow, 1979, 1980; Goldberger, 1973, Gupta, 1971; and Ram, 1982, 1984).

As discussed briefly above, the variable rate-of-growth model provides an alternative specification of the impact of dependency on aggregate saving that is especially germane to the high growth economies of East Asia (Mason, 1981, 1987, 1988; Fry and Mason, 1982). In the classic life-cycle saving model, on which the variable rate-of-growth model is based, household saving is dominated by the pension motive. Households save during their working years in order to support consumption through dis-saving during their retirement years. Given these circumstances more rapid growth in either income or population is hypothesized to lead to high rates of saving because the saving of young households will dominate the dis-saving of old households. With rapid population growth, young households will be more numerous. With rapid growth in per capita income, young households will have greater lifetime wealth.

Although much of the debate over the life-cycle saving model has focused on whether elderly households actually dis-save, dis-saving is not a necessary condition for the rate of growth effect. Rather, if households earn income at a younger age than they consume it, an increase in the rate of growth will lead to higher saving. More formally, in a steady-state equilibrium:

$\partial \ln (c) / \partial g=A_{y}-A_{c}$

where $c$ is the ratio of aggregate consumption to aggregate income and $A_{y}$ and $A_{c}$ are the population weighted average ages of earning and consumption, respectively.

The classic life cycle model emphasized changes in the age distribution of the adult population, i.e., changes in the old-age dependency ratio. How should changes in youth dependency be factored into the model? The variable rate-of-growth model distinguishes two possibilities. First, changes in the number of children may affect the timing of household consumption relative to household earning, i.e., $A_{y}-A_{c}$. Most obviously, the average age of consumption may be lower in populations with more children. (See Mason, 1987 for a detailed discussion of the relationship between income, consumption, and the number 
of children.) If this is so, equation 1 implies that a decline in youth dependency will increase saving by an amount that depends on the rate of economic growth. In a rapidly growing economy the impact will be more substantial. In a no-growth economy, changes in the timing of consumption (or earning) have no impact on aggregate saving.

A second possibility is that variation in the number of children may affect bequests or the level of lifetime consumption. There is no a priori basis for hypothesizing either a negative or a positive effect. The impact on aggregate saving of variations in bequests is independent of the rate of economic growth (Mason, 1981).

Results from the applications of the variable rate-of-growth model have varied depending on the context. The analysis of international cross-section data by Mason (1987) found evidence that youth dependency had a more robust impact on the timing rather than the level of consumption. In a recent comparison of the Leff and variable rate-of-growth models, Kelley and Schmidt (1996) finds that the variable rate-ofgrowth model is consistently superior to the Leff specification and further that the level effects are more important than the timing effects.

Several applications to Asia have yielded varied assessments of the respective importance of the timing and level effects, but find, on net, that an increase in youth dependency depresses aggregate saving (Fry and Mason (1982), Collins (1991), and Kang (1994)). Although not always statistically significant, a rise in youth dependency consistently is found to work interactively with the rate of economic growth to depress aggregate saving. This result is consistent with the principle features of Asian saving described above. First, the high rate of saving as compared with other countries can be explained by high economic growth working in tandem with a low rate of youth dependency. Second, the historical upward trend in saving can be explained by the decline in youth dependency combined with a high rate of economic growth. Third, the more recent decline in saving in Japan is consistent with the impact of slowing population growth on the relative size of the elderly population.

\section{Unresolved Issues}

There are a number of important unresolved issues and empirical features of Asian households that have an important bearing on aggregate saving rates. The first is the issue of dynamics. Most saving models are, by and large, comparative static models. The variable rate-of-growth model, for example, considers the implications for saving of high versus low fertility rates in a stable equilibrium. These two conditions would be approximated by a population which had not yet begun its demographic transition or had long since completed its transition. The countries of East Asia are, in contrast, in the midst of their transitions. Consequently the saving behavior of young households, at the current time, might be consistent with that likely to be observed in a low fertility regime. But older households (women) averaged well more than two children. Even though older women have completed their child rearing, their saving behavior would be consistent with a higher fertility regime. Williamson and Higgins (1997) make an important step forward, exploring this issue using an overlapping generations model.

Second, the household as conceptualized in the simple life-cycle model is essentially a nuclear household relying exclusively on the resources generated over the lifetime of an adult husband and wife. This is a substantial abstraction from the reality of family life in any society including those in the West. But it is a particularly poor representation of Asian households. In East Asia, the importance of the multigeneration extended household has poorly understood implications for aggregate saving.

According to the life cycle saving model, people save largely in order to fund consumption during their retirement years. Two separate lines of research on saving in developed countries have augmented or 
challenged the life cycle saving theory by emphasizing the role of interage transfers. Kotlikoff and Summers (1981) have argued that people save primarily because they wish to leave bequests to their children. Feldstein (1974) has argued that the life cycle saving motive is undermined by the public provision of PAYGO savings, another sort of intergenerational transfer. Given the importance attached to transfers as a key element for understanding saving behavior in the developed countries, it is odd that so little attention has been paid to the role of intergenerational transfers in explaining saving behavior in the Third World. Yet it is widely realized that in traditional societies, and in many countries that are already quite highly developed, the principal means of support in old age is through transfers from the elderly person's adult children, often facilitated by co-residence. This central role of children has been confirmed through cross cultural surveys on motivations for child bearing, through analyses of patterns of coresidence, through ethnographic studies, and through empirical studies of the life cycle savings hypothesis in such settings, and indeed in more modern settings during the transition to market economy. In many East Asian countries, even those that are substantially industrialized, the familial support of the elderly remains very important, even in Japan. Nonetheless, there is no question that the familial support system is weakened by various aspects of economic development and demographic transition such as a greater probability that children have moved away from the rural areas in which their elderly parents reside, occupational and geographic mobility that weakens the economic dependence of children on their parents, the availability of alternate instruments for saving and risk spreading, and so on. One implication is that models that assume that all of old age consumption is provided for through accumulated assets must greatly overstate the life cycle motive for saving. Another implication is that the "transfer transition" may itself provide a strong reason to expect saving rates to rise. Furthermore, the problems in moving from a family-based system of old age support to life cycle saving or a funded pension system, exactly parallel the problems of moving from a public PAYGO system of support to a fully funded system: in both cases, there is a generation which must provide both for its parents' retirement and for its own.

Modeling of the bequest motive requires particularly careful attention in the context of such rapid increases in productivity that if sustained, would mean that each generation would have income ten times higher than the preceding. In such circumstances, one would expect the bequest motive to be very much weakened, and perhaps reversed.

Third, the increase in educational attainment and other costly investments in children is largely ignored, although it may itself play an important causal or joint role in the decline in fertility, and it certainly has important implications for the study of savings behavior. On the one hand, the expenditure on children's human capital might be viewed as a kind of saving and investment. Indeed, such investment might be motivated in part by the desire to provide optimally for the parent's own old age security. Knodel et al (1987) report on focus groups studies in which it was said, in reference to old age support which they refer to as repayment: "Two children with education can repay better than ten [without]" (p.153). Increasing expenditures on child quality may mean that the simple assumptions going into most life cycle savings models, in which children have a fixed cost, miss the mark; conceivably, the total expenditure on all children might not decline when fertility does, due to rising per child expenditures.

Fourth, the relationship between economic growth and age-earnings profiles in the fast growing East Asian economies appears to be inconsistent with standard assumptions of the life cycle saving model. The life cycle model typically assumes a fixed longitudinal income profile. Economic growth is assumed to shift the profile uniformly upward, in percentage terms, cohort by cohort. However, the data from East Asia, Taiwan especially, is more consistent with a fixed cross-sectional profile and a longitudinal profile that rises with age and the rate of economic growth (Carroll and Summers, 1991; Deaton, 1989; Deaton and Paxson, 1994). The implications of the alternative specification of the age-earnings profile 
have not been fully explored, but it is obvious that the average age of earning will rise with the productivity growth rate in this case.

Fifth, the frequently used models of saving behavior that imply long or infinite planning horizons have been frequently challenged and there are aspects of consumer behavior that may be inconsistent with the standard assumptions employed in life cycle or permanent income models. For example, the longitudinal age profile of consumption may be inconsistent with models that assume households are primarily saving so as to smooth income over the life cycle. Given standard assumptions, one might expect young households in a rapid economic growth context to engage in enormous dis-saving so as to support consumption levels consistent with a lifetime income that far exceeds their current income. In fact, we do not observe this phenomenon in East Asia. Rather we find in longitudinal data that consumption increases rapidly with age and it is by all appearances highly correlated with income (Deaton, 1989; Carroll and Summers, 1991).

\section{Plan of Analysis}

We begin with the observation that there is a strong age pattern to people's consumption and earning streams over the life cycle. In childhood, people consume far in excess of their earning, as they also do in old age, while in the prime working years they produce more than they consume. This life cycle pattern gives rise to a demand for wealth (positive or negative) at each stage of the life cycle. We might say that a child has a demand for negative wealth, or debt, because the child must begin its life cycle by consuming more than it earns, and thereby in some general sense goes into debt. A prime age worker, and anyone older, has a demand for positive wealth, to be spent down in old age. Under various assumptions, we could calculate the life cycle pattern of the demand for wealth, L(x) (see, for example, Tobin, 1967, Figure 2 or Figure 6, or Lee, 1996). The demand for wealth can be met by two very different kinds of assets: capital, or physical wealth, $\mathrm{K}(\mathrm{x})$, on the one hand, and transfer wealth, $\mathrm{T}(\mathrm{x})$, on the other. Transfer wealth at age $\mathrm{x}$ is defined to be the difference between the present values of expected survival weighted transfers to be received and to be made over the remainder of the life cycle. At each age $x$, we have the identity: $L(x)=K(x)+T(x)$. If we aggregate across people of all ages in the population, weighted by the numbers at each age, then we get the aggregate identity: $\mathrm{L}=\mathrm{K}+\mathrm{T}$ (see, for example, Kotlikoff and Summers, 1981, and Lee, 1994).

Physical capital can be held in the form of household assets, such as farm land, structures, life stock or consumer durables, or it can be held in the form of equity in other production enterprises. The former are dominant in preindustrial societies, while the latter become increasingly important in industrial societies. Transfer wealth can be held in a familial form, for example as the expectation of future support from one's children, or in the form arising from public sector transfers, as in the expectation of a government pension, paid for by taxes. Familial transfer wealth is dominant in preindustrial societies, while public sector transfer wealth becomes important mainly in later stages of industrialization (although some Latin American countries have introduced extensive pension programs earlier on).

From this perspective, we must ask:

- In what ways should changes in fertility and mortality alter the demand for wealth at each stage of the life cycle?

- How should the changes in the population age distribution to which they give rise alter the aggregate demand for wealth by shifting the population weights for different life cycle stages?

- How should these changes alter the aggregate proportion of output that is saved? 
- How do these results differ when transfers for old age support change?

- How do these results differ when transfers to children, for example for education, change?

In addition, we will need to consider a range of assumptions about interest rates, productivity growth rates, rates of subjective time preference, and the elasticity of intertemporal substitution for consumption.

First, we will use a comparative steady state analysis to address the questions just raised. Then, we will do a dynamic analysis.

Our analysis builds on the Tobin (1967) life cycle saving model. We incorporate actual East Asian demography, incorporate explicit intergenerational transfers for old age support, and use a more general specification of the intertemporal utility function. In the first stage, we will keep Tobin's steady state assumption. In the second stage, we will do a dynamic simulation in which fertility and mortality vary, and we take the trajectories of interest rates and productivity growth rates to be given exogenously by their historical values. The dynamic simulation model does not yet include familial transfers. Finally, in a stage not yet completed, we plan to embed our saving model in a growth model, which will enable interest rates, productivity growth rates, saving and capital accumulation all to be endogenous. Note that our analysis will make the usual assumptions about the life cycle saving model but it should be born in mind that there is evidence from Taiwan inconsistent with these assumptions. (See Deaton and Paxson, 1997).

\section{Demography and Life Cycle Savings Across Steady States}

The model and assumptions are described in detail in Appendix A; here we will just discuss them in general terms. The basic unit of analysis is the household, consisting of a single adult and this adult's children. Children are assumed to set up their own households when they reach age 21 . Old age support through transfers is achieved by transfers to the household of the elderly parent, not by incorporation in the adult child's household. Each adult knows the probabilities of survival for self and for children, for all ages, and takes these into account in planning. Uncertainty about age at death is absorbed by institutions with which we do not concern ourselves. Each adult also knows the interest rate and the across-all-ages growth rate in earnings, as well as knowing the cross-sectional age earnings profile for all ages. With this information, the adult is able to calculate the present value of the survival weighted earnings of all members of the household; for children, only the years up to age 21 are counted. The adult calculates the expected, survival weighted, number of equivalent adult consumers (EACs) in the household for each year of its existence, and derives consumption utility from the product of this number of EACs in each year, times some function of consumption per EAC in the household. The specification is chosen so that the marginal utility of total household consumption each year depends only on the consumption per EAC, and not on the number of EACs in the household. The adult then plans a life cycle trajectory of total household consumption to maximize an intertemporal utility function, depending on a subjective rate of time preference and on the elasticity of intertemporal substitution. From the trajectories of earnings and consumption, and from the interest rate, we can calculate the trajectory of household assets. Using this, we can calculate total household income, including income from both labor and the asset, and subtracting consumption from this we find household savings at each age.

Familial transfers for old age support are treated as follows. We define an index $t$ which describes the size of the total transfer received by an elder at age 60 and above. This index measures the fraction of the gap between the earnings of a current 40 year old male, and the current earnings of the elder, that is made up by the familial transfer. Thus for $t=1$, the elder would have total income equal to the labor earnings of 
a 40 year old. The cost of this transfer is born equally by all the surviving children of the elder. Any given value of $t$ defines a stream of transfers made or received across all ages over the life cycle, call it $\tau(\mathrm{x})$, and $\tau(\mathrm{x})$ is simply added to the household labor earnings at each age. Bequests can be handled in a similar manner.

For the comparative statics, we define a baseline set of assumptions, and examine the effects of deviations from this baseline. The baseline set of assumptions is a life expectancy of 54 years, a total fertility rate of 3.1 children per woman, a rate of interest of 5 percent and of productivity growth of 3 percent, and a zero rate of time preference. There are no transfers from adult children to their elderly parents for old age support, and there is no bequest motive. Children $0-4,5-9,10-14$, and 15-18 have Equivalent Adult Consumer (EAC) weights of .3, .4, .6 and .7, while all others have weights of unity. The intertemporal elasticity of substitution is a key parameter in our model of life cycle consumption, as explained in the Appendix A. For the US, there is a rough consensus on the range .2 to .35 (Auerbach and Kotlikoff, 1987). For Third World countries, and for Taiwan in particular, we are fortunate to have a recent study by Ogaki et al (1996) which finds a value of .6 for Taiwan and for other countries in the same income class. We have used this value in our steady state and dynamic simulations.

The tables below report the results of simulations in which one or two of these assumptions are varied, while all others are kept at the baseline levels. From these simulations, as reported in the tables, we learn the following regarding comparative steady states:

- Mortality decline strongly raises savings rates $(-.01$ to +.07$)$ and wealth (K/Y from -.37 to 1.52$)$, see Table 1.

- Fertility decline has little effect on savings rates, but strongly raises wealth (K/Y from .54 to 2.02 ), see Table 2.

- When mortality and fertility decline together, saving rates rise (.03 to .09) and wealth rises strongly $(\mathrm{K} / \mathrm{Y}$ from .62 to 3.62$)$, see Table 3.

- When productivity rises by itself, savings rates decline sharply (.031 to -.54$)$, as does wealth $(\mathrm{K} / \mathrm{Y}$ from 3.34 to -7.7 ), see Table 4.

- When interest rates rise while productivity is fixed, savings rates rise $(-.066$ to +.073$)$ and wealth rises $(-2.3$ to +2.5$)$, see Table 5 .

- When productivity growth rates and interest rates rise together, savings rates decline strongly $(+.02$ to -.13), as does wealth ( $\mathrm{K} / \mathrm{Y}$ from 2.6 to -1.9$)$, see Table 6 .

- Old Age Support through transfers strongly reduces savings and wealth, see Table 7.

- Increased investment in children, holding fertility constant, reduces saving and wealth (defined narrowly for physical capital), see Table 8.

While some of these results depend sensitively on the elasticity of substitution, the effects of demographic differences appear to be fairly robust. Note that not one of these many steady states generates an aggregate saving rate as high as $+10 \%$. But also note that demographic changes across the demographic transition generate an increase in the capital output ratio from .6 to 3.6, which is very large. Combined with the fact that per capita income was growing at around 5 or $6 \%$ per year, this implies a massive increase in capital per worker, by a factor of 70 or so $\left[71=(3.6 / .6)^{*}\left(\exp \left(45^{*} .055\right)\right)\right]$. In order to 
Table 1. Steady State Effects of Different Mortality Regimes With Other Variables Set At Baseline Values

\begin{tabular}{c|ccc}
$\mathrm{e} 0$ & $\mathrm{~s}$ & $\mathrm{~K} / \mathrm{YI}$ & $\mathrm{K} / \mathrm{Y}$ \\
\hline $\mathbf{2 9 . 0 0}$ & -0.01 & -0.36 & -0.37 \\
$\mathbf{4 4 . 0 0}$ & 0.00 & 0.13 & 0.13 \\
$\mathbf{5 4 . 0 0}$ & 0.01 & 0.35 & 0.35 \\
69.00 & 0.05 & 1.21 & 1.14 \\
$\mathbf{7 5 . 0 0}$ & 0.07 & 1.65 & 1.52
\end{tabular}

Table 2. Steady State Effects of Different Fertility Regimes With Other Variables Set At Baseline Values

\begin{tabular}{c|ccc} 
TFR & s & K/YI & K/Y \\
\hline 6.34 & 0.03 & 0.56 & 0.54 \\
3.94 & 0.01 & 0.31 & 0.31 \\
3.14 & 0.01 & 0.35 & 0.35 \\
2.45 & 0.03 & 0.99 & 0.94 \\
1.72 & 0.03 & 2.25 & 2.02
\end{tabular}

Table 3. Steady State Effects of Fertility and Mortality Varying Together, With Other Variables Set At Baseline Values

\begin{tabular}{c|cccc} 
TFR & E0 & s & K/YI & K/Y \\
\hline 6.34 & 29.00 & 0.03 & 0.64 & 0.62 \\
3.95 & 43.50 & 0.01 & 0.14 & 0.14 \\
3.14 & 53.50 & 0.01 & 0.35 & 0.35 \\
2.45 & 69.00 & 0.07 & 2.05 & 1.86 \\
1.72 & 75.90 & 0.09 & 4.42 & 3.62
\end{tabular}


Table 4. Steady State Effects of Productivity Growth Varying With Interest Rate Fixed at .03, With Other Variables Set At Baseline Values

\begin{tabular}{c|ccc}
$\mathbf{g}$ & $\mathbf{s}$ & $\mathbf{K} / \mathbf{Y}$ & $\mathbf{K} / \mathbf{Y}$ \\
\hline $\mathbf{0 . 0 0}$ & 0.031 & 3.71 & 3.34 \\
0.02 & 0.008 & 0.26 & 0.26 \\
0.04 & -0.153 & -2.86 & -3.12 \\
0.06 & -0.536 & -6.24 & -7.68
\end{tabular}

Table 5. Steady State Effects of Interest Rate Varying With Productivity Growth Fixed at .02, With Other Variables Set At Baseline Values

\begin{tabular}{c|ccc}
$\mathbf{r}$ & $\mathbf{s}$ & $\mathbf{K} / \mathbf{Y}$ & $\mathbf{K} / \mathbf{Y}$ \\
\hline $\mathbf{0}$ & -0.066 & -2.27 & -2.27 \\
$\mathbf{0 . 0 2}$ & -0.017 & -0.57 & -0.57 \\
$\mathbf{0 . 0 4}$ & 0.031 & 1.11 & 1.06 \\
$\mathbf{0 . 0 6}$ & 0.073 & 2.92 & 2.49
\end{tabular}

Table 6. Steady State Effects of Interest Rates and Productivity Growth Varying Together, With Other Variables Set At Baseline Values

\begin{tabular}{cc|ccc} 
Interest Rate & Prod Growth & s & K/YI & K/Y \\
\hline 0.02 & 0.00 & 0.02 & 2.75 & 2.60 \\
0.04 & 0.02 & 0.03 & 1.11 & 1.06 \\
0.06 & 0.04 & -0.02 & -0.36 & -0.37 \\
0.08 & 0.06 & -0.13 & -1.68 & -1.94
\end{tabular}


Table 7. Steady State Effects of Different Levels of Familial Transfers to Elderly, With Other Variables Set At Baseline Values

\begin{tabular}{c|ccc} 
Level of Transfers & $\mathbf{s}$ & $\mathrm{K} / \mathrm{YI}$ & $\mathbf{K} / \mathbf{Y}$ \\
\hline $\mathbf{0 . 0}$ & 0.014 & 0.35 & 0.35 \\
0.2 & -0.025 & -0.63 & -0.65 \\
0.4 & -0.069 & -1.62 & -1.76
\end{tabular}

Note: The level indicates the fraction of the gap between current earnings of a 40 year old and of an elder at each age which is made up by transfers to the elder from all the surviving children.

Table 8. Steady State Effects of Different Levels of Parental Investment in Children, With Other Variables Set At Baseline Values

\begin{tabular}{c|ccc} 
Investment Per Child & s & K/YI & K/Y \\
\hline $\mathbf{0 . 2 5}$ & 0.040 & 1.08 & 1.02 \\
$\mathbf{0 . 5 0}$ & 0.014 & 0.35 & 0.35 \\
$\mathbf{0 . 7 5}$ & -0.008 & -0.20 & -0.20
\end{tabular}

Note: Investment per child indicates the consumption by a child (averaging across ages) as a fraction of consumption by an adult (that is, the average EAC weight for a child). 
achieve this massive increase in the capital stock over the course of 45 years, net savings rates would have had to be much higher than $10 \%$ during this transitional phase. Williamson and Higgins(1997) rightly stress that comparative steady state analyses could be very misleading, and that we need studies of the transitional dynamics. This encourages us to do a dynamic simulation of savings and capital accumulation which take into account the changing age distribution during the transition, to which we will now turn.

\section{Dynamic simulations}

Ultimately we intend to perform simulations in which interest rates and productivity growth rates are determined endogenously along with savings rates and wealth, using a growth model fit to Taiwanese experience. For the moment, however, we will restrict ourselves to a simpler task, in which interest rates and earnings growth rates are treated as exogenous, and taken from the historical record.

Whereas in steady state models it is appropriate to assume that all actors have full information about the future, the situation is more complicated in a dynamic simulation. Here we simulate two scenarios. In the first, we will assume that adults only know current period demography. In the second, we will assume that all adults have full knowledge of their future fertility and of future cohort mortality, including that of their children. (It is arguable that it would make more sense to assume that adults are ignorant of future mortality, while knowing future fertility. We plan to implement this as a third scenario). They also know the shape of cross-sectional age earnings profiles, averaged across males and females, and therefore they implicitly know future trends in labor supply for both men and women. However, they do not know what future real interest rates will be, and they do not know how rapidly the level of the age-earnings profile will be rising. We make an ad hoc assumption about how these expectations are formed. We assume that adults form an estimate of the current underlying rates of interest and wage growth by averaging levels in the current and previous four years. But we also assume that they do not necessarily expect these average real interest rates and earnings growth rates to continue indefinitely into the future. Instead, they project a gradual exponential change from the current underlying rates to some given ultimate levels of the rates. In our base scenario, these ultimate rates are set at three percent per year for the real interest rate, and at 1.5 percent per year for the growth rate of earnings. These are both well below the averages over our period of observation, 1950 to 1990 , which were .074 and .055 , respectively. Our rationale is that adults might look to the experience of the US or other high-income countries to assess their own long run future. Experience with the simulations, to be described later, suggests that expectations should be even less responsive to current events than we have made them be.

Given this assumed knowledge about current or future demography, and about future earnings and interest rates, each household solves the same optimization problem as was outlined earlier (and in Appendix A) for the static model. However, they must re-solve it each year new information becomes available from current interest and earnings growth rates, and so they must re-solve the optimization problem, taking their actual holdings of wealth in the current year as given. Typically they will find that the amount of wealth they actually hold does not correspond to their optimal amount under the new circumstances. Thus each year they revise their plans, and consume, save and invest accordingly. Note also that to form their optimal plans, they have to look ahead to the end of their life cycle, which we assume to occur at age 100. Of course, very few people survive into extreme old age, and adults take these survival probabilities into account when formulating their plans. Twenty-one year olds adult in 1994 must project their future fertility and mortality all the way out to 2073. In practice, we have given them expectations corresponding to the official projections of the Taiwanese government. We have used these projections to consider savings rates through 2100 , requiring projections through 2179 . Obviously projections so far into the future are extremely uncertain. But what matters most is not what actually happens, but what people will expect to happen. The dynamic model is described in detail in Appendix B. 
Figure 3 plots real rates of interest and rates of earnings growth from 1950 to 1990 or so. Clearly both have been fairly volatile, and there was a huge negative spike in the interest rate during the oil crisis of the 1970s. When interest rates or earnings rates change dramatically, there will be dramatic effects on expectations about the future, which can lead to sharp changes in savings behavior. Preliminary simulations using these actual interest rates and earnings growth yielded a very erratic pattern of savings rates, as well as capital-output ratios. The interest rate of -33 percent in 1974 had a huge influence, since holders of capital stock lose a third of it in one year, at the same time that the present value of their future earnings rises through the roof! While such predictions of the model are not entirely without interest, they do not advance our understanding of the role of demographic change, so we performed simulations in which the interest rate was fixed at its average value for the period 1950-1994 of $7.4 \%$ and the earnings growth rate at 5.5\%. After 1994, the rates were assumed to slowly drift downward (closing $10 \%$ of the gap each year) toward a long run interest rate of $3.0 \%$ and earnings growth rate of $1.5 \%$.

Figure 4 shows the results of the 2 simulations, one in which actors are ignorant of future demographic changes (solid line) and one in which actors are assumed to know their future demography (dashed line). In the first simulation, savings rates begin at about $8.5 \%$ in 1950 and decline a bit initially before beginning a sustained climb to about $18.5 \%$ in 2010 . The savings rate then declines gradually, stabilizing at about $6.5 \%$, slightly below initial levels. In the second simulation, savings rates begin at a higher level of $16.5 \%$ in 1950 and then decline to $7.6 \%$ in 1974 before beginning a sustained climb to $20.5 \%$ in 2006 . The rate then declines gradually to a level of about $6.5 \%$. It is surprising to see the significant difference in savings behavior in the two models for the period 1950-1960. We are currently investigating the source of this difference which ultimately lies in our assumption that actors anticipate future changes in fertility and mortality. When dependency ratios fall during the period 1970-2005, we find both simulations showing significant increases in savings rates due to life cycle savings. When dependency ratios are rising in the post 2005 period, we again find close agreement between the simulations showing declines in savings rates and eventual stabilization at $6.5 \%$-in close agreement to results from the static analysis.

It is also instructive to compare the timing of these changes to the earlier figure which showed the changes over time in the support ratio. In our model, both the historical demographic change experienced by a cohort, and anticipated future changes, will affect current savings behavior, so the current age distribution (and the economic support ratio) may be a faulty guide to current savings behavior. This is one potentially serious problem for the many empirical studies relating contemporaneous age distribution and savings behavior. However, we generally find close agreement between the economic support ratio and the timing of savings changes except in the initial years of the simulation.

The next figure plots the changes in the capital-output ratio that are implied by the time path of savings rates. The ratio rises from a very low level (around .3) in 1950 to a plateau of about 5 in 2030 (Figure 5).

Clearly, these dynamic simulations tell a dramatically different story than do the steady state simulations, confirming the point made by Higgins and Williamson. While steady state simulations closely match the dynamic ones after population stabilization, they are obviously incapable of capturing the magnitude of the increase during the transition. To what extent is the increase in savings in Taiwan accounted for by the demographic transition? In our simulations, we find large increases in savings over the period of the demographic transition from 1970 to 1993 . Savings increase by 7.5 to 9.8 percent-roughly one-half to two-thirds of the actual change in savings over the period. 


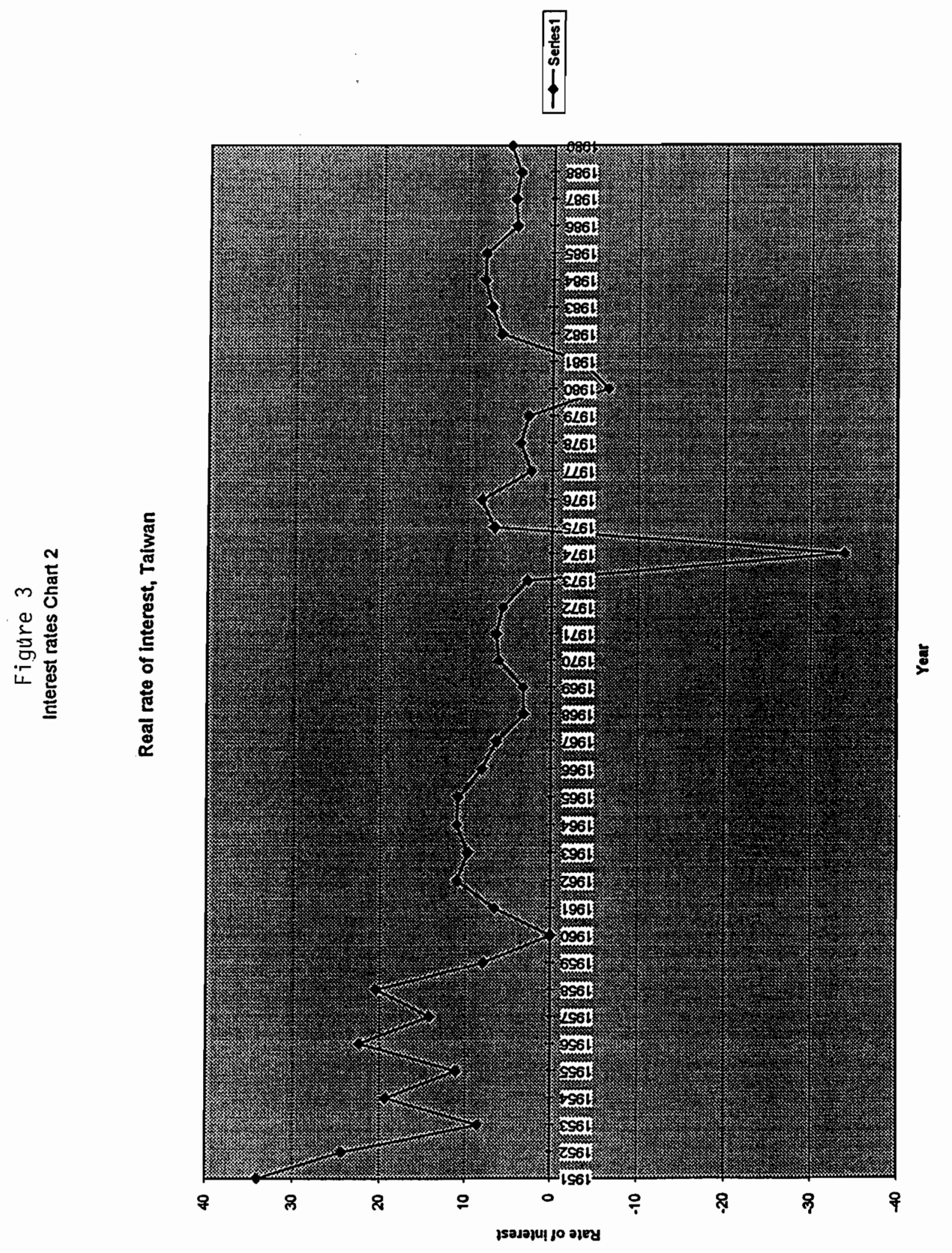




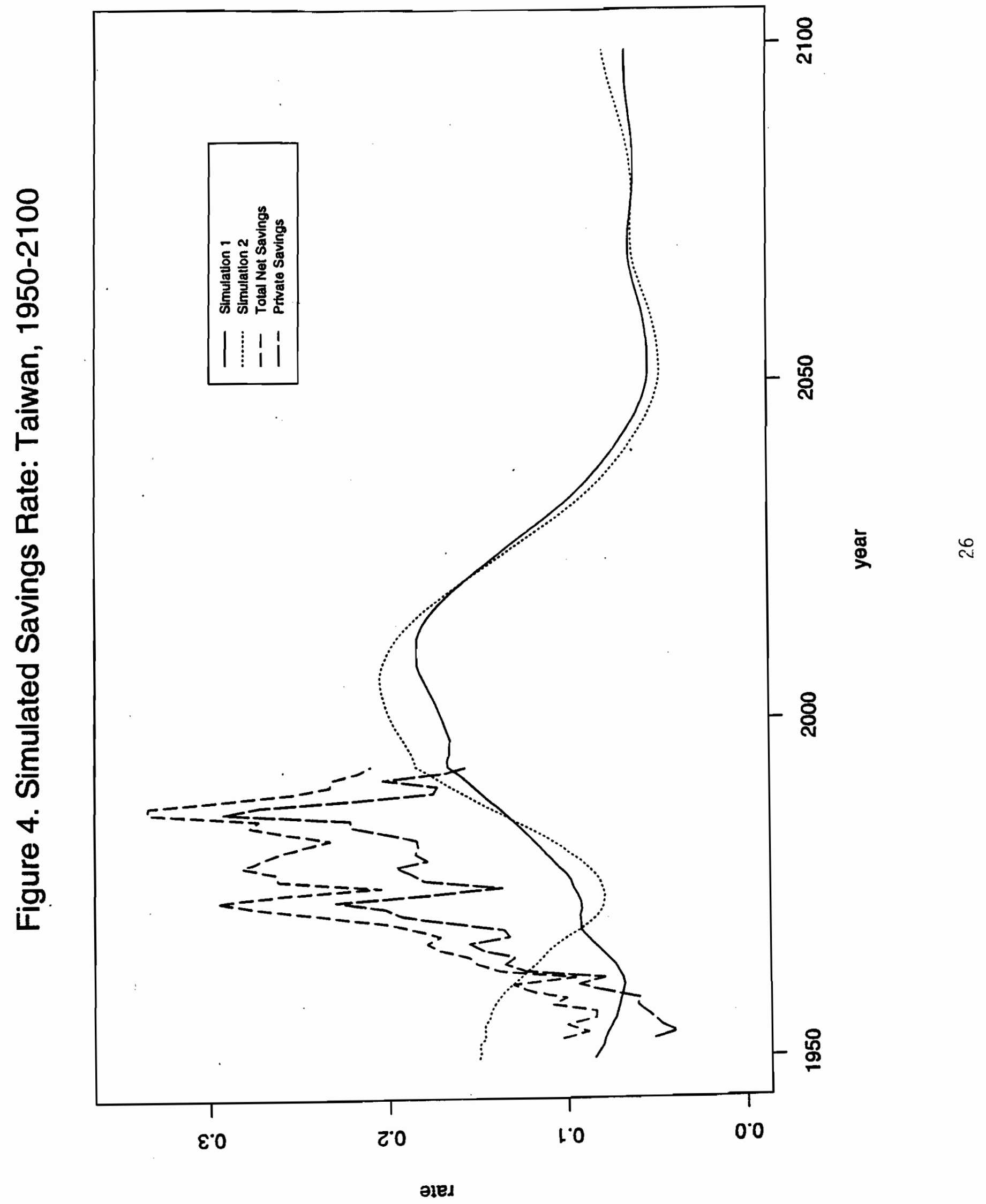




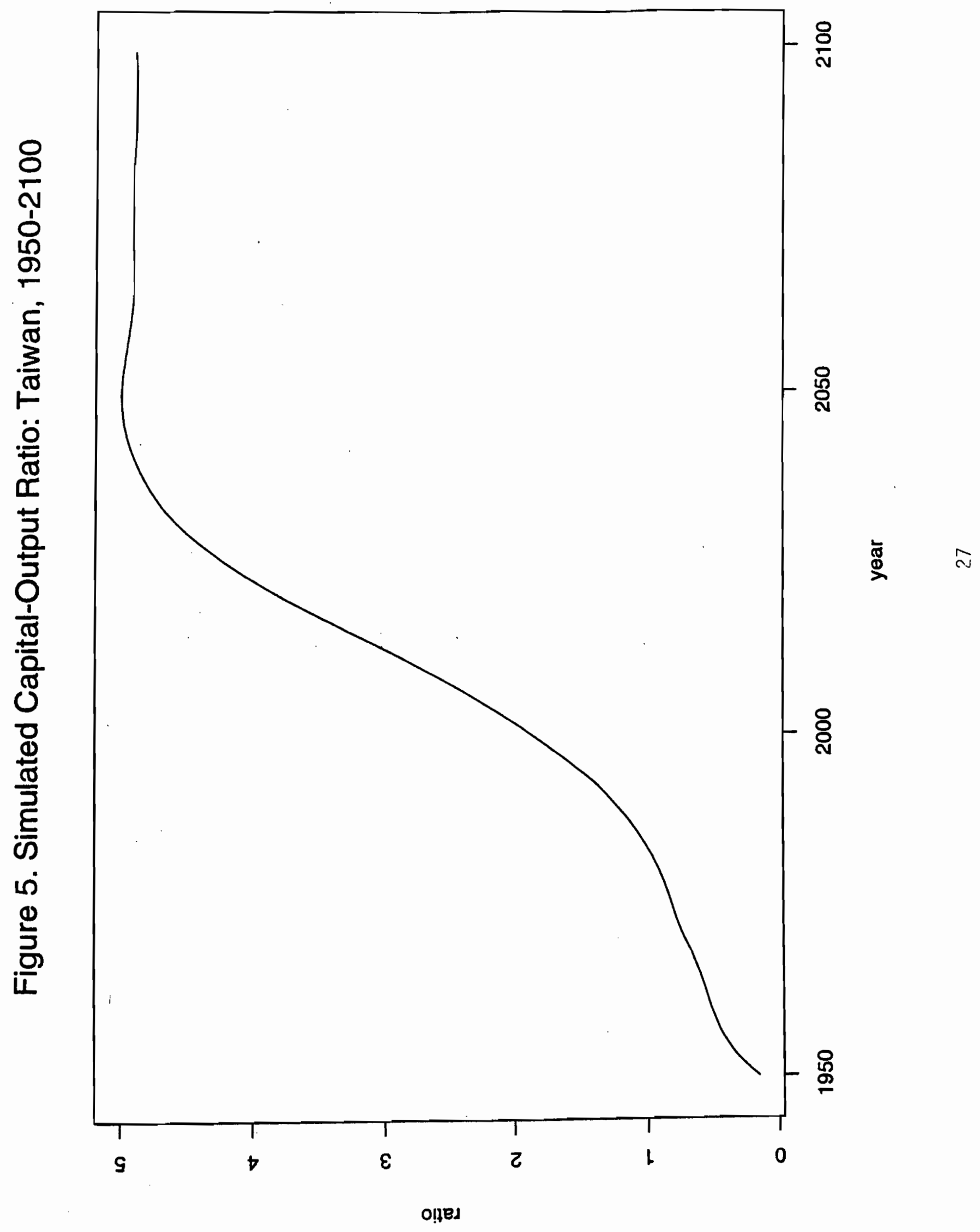


We must keep in mind, however, that the principal means by which the elderly are supported in Taiwan and the rest of East Asia is not by drawing down on their earlier savings, as the life cycle savings model assumes, but rather through inter-familial transfers. We have not yet incorporated these in the dynamic simulation, although we do plan to do so in the future. As the steady state analysis showed, old age support through transfers has a dominating effect on savings and capital formation. At a minimum, we should reduce the size of the swing in savings rates that could be accounted for by the life cycle saving hypothesis. Our dynamic simulations, by ignoring transfers to the elderly, probably overstate the effects of demographic change on capital accumulation. At the same time, the weakening of the familial old age support system which has accompanied economic development is itself an additional cause of the increase in savings rates.

\section{Conclusions}

The stylized demographic transition revealed characteristic trajectories for the dependency ratios. Child dependency first rose, then fell strongly. Old age dependency rose throughout the transition. Total dependency first rose, then fell steeply, then rose again, ending up roughly where it began. Evidently, a comparative stable population analysis of the effect of the transition on the total dependency ratio would show little change, although the transitional dynamics are in fact dramatic.

For Taiwan, our data on the population during the transition were used to calculate a refined dependency ratio, the economic support ratio-giving for each year the equivalent adult producers in the population divided by the equivalent adult consumers. The ratio was calculated for the period starting around the time of the initiation of fertility decline, and therefore it missed the initial deterioration in the dependency ratios when mortality first declined. We saw that this ratio rises by 22 to 28 percent between 1970 and 2010, indicating that consumption at each age could rise by this amount even if there was no change in the productivity of labor. Alternatively, this additional "demographic bonus" could have been used to raise savings.

Under the assumption that consumption and saving behavior were governed by the desire to smooth consumption over life cycle variations in expected household earnings-in effect, to provide for old age retirement-we explored how this demographic bonus would be utilized. Our first analysis was comparative steady state, simply comparing the implications of the pre-transitional and post-transitional age distributions. We found that lower mortality implied substantially higher savings rates, and a substantially higher capital/output ratio. Lower fertility implied no change in savings rates coupled with a higher capital/output ratio. When fertility and mortality change together from high levels to low levels, as happens eventually across the transition, savings rates rise modestly, but the capital output ratio rises considerably. Since we are examining net savings, it is possible to have either a high or low capital output ratio with the same saving rate. This tells us that we should not expect the demographic transition to lead to a large permanent change in the saving rate, even though longer life and lower fertility will lead to a substantial increase in the demand for wealth, and in the amount of capital per worker and per unit of output. Dynamic analysis is necessary in order to see what transpires between these two steady states, and how the economy moves from a low wealth situation to a situation in which there is a high level of capital per worker.

Our dynamic analysis revealed significant increases in savings occurring over from 1970-2005. This is followed by decreases in savings rates over the first half of the $21^{\text {st }}$ century, until rates stabilize at close to initial levels. Taking these results at face value, we would conclude that the demographic transition in Taiwan significantly contributed to the increase in the saving rate since 1970. 
Although the simulated saving path mirrors the rise of savings experienced in Taiwan during the 1970s and 1980s, many important features of Taiwan's saving are not captured by the dynamic life cycle model. Saving rates rise more substantially during the transition than do the simulated rates, they are much higher in most years than is consistent with savings motivated solely by lifecycle smoothing, they are rising steadily throughout the $1950 \mathrm{~s}$ and $1960 \mathrm{~s}$ in contrast to our simulated rates, and they are subject to short term influences which are not captured by the lifecycle model we have employed.

Returning to the question with which we started, recall that there was a 22 to 28 percent decrease in the refined dependency ratio, providing the demographic bonus. Our simulations indicates that the saving rate rises by 8 to 10 percent over the same period. It appears, therefore, that between one-third to one-half of the entire demographic bonus would be saved under the life cycle saving hypothesis.

Demographic aging will lead to declines in savings rates in the $21^{\text {st }}$ century. By 2050 , savings rates are forecast to decline to pre-transition levels, but the equilibrium capital output ratio will have increased more than 10-fold as compared to 1950.

But this discussion has taken our results at face value, ignoring the role of familial transfers in the provision of old age support in East Asian populations and indeed throughout the Third World. At the beginning of this period, and more generally in the period before fertility decline, it seems likely that the familial provision for old age support was strong and pervasive throughout the region, with all generations expecting its continuation in the future. Under these circumstances, the life cycle saving motive would be very weak. Some of our comparative static simulations depicted this situation, and showed that indeed strong familial transfers for old age support would lead to very low savings and corresponding low capital output ratios. There is abundant evidence, however, that expectations for continuation of the familial old age support system are radically changing, and have been changing over recent decades. While elderly co-residence with adult children remains high throughout the region, it is declining, and surveys show weakening expectations. Under these circumstances, the working age population is beginning to feel obliged to provide for its own old age support through life cycle savings. This generation is caught in a squeeze, for it must both make transfers to its elderly parents and at the same time provide for its own retirement through saving. This is precisely the situation of young workers in those OECD countries which are instituting privatized or funded public pension programs. The transition from public or familial transfer based old age support to public or private funded old age support places a double burden on the transitional generation.

Savings and wealth should rise for two reasons, therefore: first, because of the demographic transition, and second, because of the transition from familial transfers to funded provision for old age support. 


\section{APPENDIX A. Details of the static model underlying the life cycle saving simulations}

\section{Demography:}

The household consists of one adult and his or her dependent children. We assume that children leave home to form their own households at age $z$, an average for male and female children. We take $p(x, t)$ to refer to cohort survival to age $x$ for those born in year $t-x$. The expectation that the household will reach age $x$ from age $z$ (the age at which all households are assumed to be formed) is expressed as $p(x, t) / p(z, t$ $x+z)$. The expected number of adults at each age $x$ is equal to $p(x, t) / p(z, t-x+z)=n(x, x, t)$.

Fertility at age $x$ is given by $f(x)=m(x) / 2$, which is half of female fertility at age $x$. The total number of surviving children produced by a parental cohort are shared among all surviving parents. That is, we assume uncles and aunts who have the same age as the deceased parent adopt orphans. The number of children at exact age $i$ for a parent age $x$ at time $t$ (for all $i<x$ ) is given by :

$$
\frac{p(x-i, t-i) f(x-i, t-i) p(i, t)}{p(x, t)}=o(i, x, t) \text { This expression is utlized later in Section } 4 .
$$

The expected number of children at exact age $i$ (for all $i<x$ ) evaluated by an individual at the age of household formation, $z$, for a future age $x$ and future time $t$ is given by :

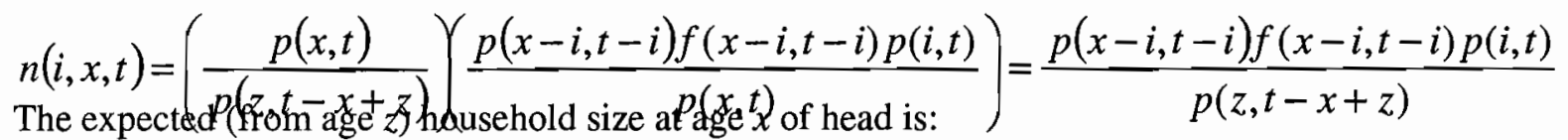

$$
\sum_{i=0}^{x} n(i, x, t)=\frac{p(x, t)}{p(z, t-x+z)}+\sum_{i=0}^{x-1} \frac{p(x-i, t-i) f(x-i, t-i) p(i, t)}{p(z, t-x+z)}
$$




\section{The Basic Household Model:}

The basic model for the household is a generalization of the one used by Tobin (1967). The notation used below assumes that interest rates and the growth in the level of the age earnings profile are constant, but the generalization to varying rates is straightforward, and is used in the dynamic simulation section later on.

$$
\begin{aligned}
& H(x)=\sum_{i=0}^{x} e(i) n(i, x) \\
& Y_{l}(x)=w(t) \sum_{i=0}^{x} l(i) n(i, x) \\
& P V\left[Y_{l}(x)\right]=\int_{z}^{\omega} \mathrm{e}^{-\mathrm{rx}} Y_{l}(x) d x \\
& P V[C(x)]=\int_{z}^{\infty} \mathrm{e}^{-\mathrm{rx}} C(x) d x \\
& V=\int_{z}^{\omega} e^{-\rho x} u[C(x), H(x)] d x
\end{aligned}
$$

With this notation, the optimization problem when the household is formed, is to choose a trajectory of $\mathrm{C}(\mathrm{x})$ so as to maximize $V$ subject to :

$$
P V\left[Y_{l}(x)\right]=P V[C(x)]
$$

Here the notation is mostly transparent. $H(x)$ is the expected household size measured in adult equivalent consumer units with $e(i)$ measuring the fractional value of consumption of an individual of age $i$ relative to an adult. $Y_{l}(x)$ is the expected household labor income with $l(i)$ measuring equivalent producer units (the geometric mean of labor income for both sexes combined over the period 1976 to 1992) and $w(t)$ representing an across-all-ages shifter for labor productivity. Often, we will assume that $w(t)=$ $w(0) \exp (\lambda t) . \quad C(x)$ represents total household consumption. Note that in this specification, the rate at which the planner gets utility from household consumption depends on household size measured in equivalent adult consumption units, in a way yet to be specified. This basic model will be enriched below by inclusion of transfers from adult children to their elderly parents, and by bequests at death from elderly parents to their children. 


\section{Life Cycle Optimization:}

Define the instantaneous household utility function to be:

$$
u[C(x), H(x)]=H(x)\left(\left[\left[\frac{C(x)}{H(x)}\right]^{1-\gamma}-1\right) / 1-\gamma\right)
$$

In this specification, household utility is proportional to the number of Equivalent Adult Consumers (EACs) in the household, denoted $H(x)$, times a standard constant relative risk aversion utility function, with consumption per EAC as its argument. This is a natural generalization of Tobin's household utility function. Although this household utility function appears to be complex, its derivative is simple:

$$
\frac{\partial u}{\partial C(x)}=\left[\frac{C(x)}{H(x)}\right]^{-\gamma}=\left[\frac{H(x)}{C(x)}\right]^{\gamma}
$$

The optimal household consumption path over the life cycle is derived below, after forming the Lagrangian and differentiating.

$$
\begin{aligned}
& \mathrm{L}=V-\lambda\left(P V\left(Y_{l}(x)\right)-P V(C(x))\right) \\
& \partial L / \partial C(x)=e^{-p x}\left[\frac{H(x)}{C(x)}\right]^{\gamma}-\lambda e^{-r x}=0 \\
& C(x)=H(x) e^{(r-\rho) x / \gamma} \lambda^{-1 / \gamma}
\end{aligned}
$$

Substituting $C(x)$ into the budget constraint yields :

$$
\lambda^{-1 / \gamma}=P V\left[Y_{l}(x)\right] / \int_{z}^{\omega} e^{-r x} H(x) e^{(r-p) x / \gamma} d x
$$

Substituting back for $\lambda^{-1 / \gamma}$ yields :

$$
C(x)=\frac{P V\left[Y_{l}(x)\right] H(x) e^{(r-\rho) x / \gamma}}{\int_{z}^{\infty} e^{-r x} H(x) e^{(r-\rho) x / \gamma} d x}
$$

From this result we can observe the following:

- Consumption is proportional to the household size measured in EAC units, other things equal;

- Consumption per EAC unit in the household rises over the life cycle at the rate $(r-\rho) / \gamma$, which becomes slower as $\gamma$ becomes larger.

- Although utility is undefined for $\gamma=1$, its derivative with respect to $C(x)$ is defined, and equals the derivative of the Tobin (1967) utility function, $H(x) \ln (C(x) / H(x))$.

- The larger is $\gamma$, the lower is the rate of intertemporal substitution, and the less responsive are consumption and saving to variations in the interest rate. 


\section{Adding Intergenerational Transfer for Old Age Support:}

Now suppose that there is an age schedule of net intergenerational transfers measured by $\tau(x)$, where positive $\tau(x)$ means that transfers received at age $x$ exceed transfers made. Note that we have already included the basic consumption costs of children by way of the $e(x)$ function, so that these will not be included here in the transfer function; rather, it will mainly reflect transfers to the elderly from their children. It will also not include bequests, which will be treated separately. A person age $x$ has $o(i, x)$ children of age $i$. Suppose that each surviving child contributes an equal share to their elderly parent. We then have the following relationship:

$\tau(x)=\sum_{i=0}^{x} o(i, x) t_{c h}=\tau_{c h} o(x) \quad$ For all $\mathrm{x} \geq 60$

where $o(x)$ is the total number of surviving children of a surviving elderly person.

It will be convenient to specify the size of the transfer to be received by an elder. For each person age 60 and above, we will set net transfers received at a fraction $\tau$ of the difference between the labor earnings of this elder at age 40 , updated to his/her current age by productivity growth in the interim (equivalently, this is a fraction of the labor earnings of a current 40 year old) and the elders current earnings. Thus if the fraction is 1.0 , then the elder would have his/her income upgraded to the income of a current 40 year old through familial transfers:

$\left.\tau(a)=\tau\left[e^{\lambda(a-40)} y_{l}(40, t-a+40)\right]-y_{l}(a, t)\right]$

Then the share to be paid by each surviving child, per surviving elder parent, can be calculated by dividing this by $o(a)$. This must be calculated so as to be consistent with the schedule of transfers received by the elderly. A surviving child at age $x$ under the age of 60 will have a surviving parent at age

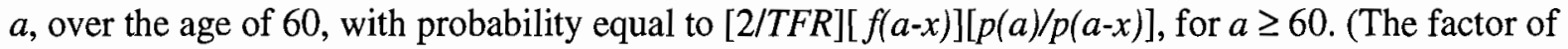
$2 / T F R$ converts the fertility distribution into a probability distribution.) The cost of supporting each such parent of age $a$ will be shared by all the surviving siblings, of whom there are $o(a)$. For such a surviving parent, the child will make a transfer of $\tau(a) / o(a)$. The total expected value of transfers made by a child age $x$ in support of elderly parents will be given by the sum over these ages $a$ :

$\tau(x)=(2 / T F R) \sum_{a=60}^{\omega}[\tau(a) / o(a)] f(a-x)[p(a) / p(a-x)]$

for $x<60$, and $\tau(x)$ for $x \geq 60$ is given by an earlier equation.

When this transfer function is added to the optimization problem, the revised budget constraint will be as before, except that $\tau(\mathrm{x})$ is added to $Y_{l}(x)$. Life cycle wealth is now given by $\mathrm{PV}(\tau)+Y_{l}$. When $r>n+\lambda$, $\operatorname{PV}(\tau)<0$, since these are upward transfers. 


\section{Bequests (not yet implemented, and to be revised.)}

Bequests will be handled as a special kind of transfer. Let "beq" be the total amount of a bequest that is left at time of death, to be divided among the surviving children. It is assumed to financed by the purchase of life insurance policy so that the uncertainty about time of death is absorbed by some market institution, not the individual. The distribution of time of death is indicated by $d p(x) / d x$. We add to the utility function a term reflecting the utility of leaving a bequest of amount beq, and here assume that this utility is independent of both the number of children and of the age of death: $v($ beq $)$. To the budget constraint, on the side of consumption, we add a term equal to the present value of the bequest amount, weighted by age at death:

$$
\int_{z}^{\omega} \mathrm{e}^{-\mathrm{rx}} \frac{d p(x)}{d x}(1 / p(z))(\text { beq }) d x
$$

Now, however, that we must also take into account that the heirs will be receiving a share of this amount, and that it must be added in to their budget constraints. Suppose that each of the $o(a)$ children receives an equal share, $b e q / o(a)$. A person at age $x$ has a probability distribution for the age of their parent, number of siblings, and probability of the parent dying.

$$
b e q(x)=[2 / T F R] \sum_{a=x}^{\infty} \frac{b e q}{o(a)} f(a-x)\left[\frac{d p(a) / d a}{p(z)}\right] .
$$

This amount should be added to $Y_{l}(x)$ at each age to form the new budget constraint.

We can approximate the age distribution of parents by assuming that all childbearing takes place at exactly age 30 . This yields this simplified budget constraint:

$$
\begin{aligned}
& \int_{\mathrm{z}}^{\omega} \mathrm{e}^{-\mathrm{rx}} Y_{l}(x) d x+\int_{z}^{\omega-30} e^{-r x} b e q \frac{1}{p(z)} \frac{d p(x+30)}{d x} \frac{1}{o(x+30)} d x+\int_{z}^{\omega-30} e^{-r x} \frac{p(x)}{p(z)} \tau(x) d x \\
& =\int_{\mathrm{z}}^{\omega} \mathrm{e}^{-\mathrm{rx}} C(x) d x+\int_{\mathrm{z}}^{\omega} \mathrm{e}^{-\mathrm{rx}} \frac{d p(x)}{d x} \frac{1}{p(z)}(b e q) d x \\
& \text { where, for } \mathrm{x}<60, \tau(\mathrm{x})=\frac{-p(x+30)(x+30)}{o(x)} .
\end{aligned}
$$




\section{APPENDIX B. Details of the dynamic model underlying the life cycle saving simulations}

1. Demography: Unchanged from the static model.

2. The Basic Model: As in the static model, except that decisions are made at all ages $x \geq z$ rather than just at age $x=z$. Expressions are evaluated at age $x$ looking forward $a$ years $[a \geq 0]$ into the future when the household head will be age $x+a$ in year $t+a$.

$$
\begin{aligned}
& H(x, a, t)=\sum_{i=0}^{x+a} e(i) n(i, x+a, t+a) \\
& Y_{l}(x, a, t)=w(t+a) \sum_{i=0}^{x+a} l(i) n(i, x+a, t+a) \\
& P V\left[Y_{l}(x, a, t)\right]=\int_{0}^{\omega-x} \mathrm{e}^{-\mathrm{ra}} Y_{l}(x, a, t) d a \\
& P V[C(x, a, t)]=\int_{0}^{\omega-x} \mathrm{e}^{-\mathrm{ra}} C(x, a, t) d a \\
& V(x, t)=\int_{0}^{\omega-x} e^{-\rho a} u\left[C(x, a, t),\left(\frac{p(z, t-x+z)}{p(x, t)}\right) H(x, a, t)\right] d a
\end{aligned}
$$

Max $V$ Subject To :

$$
\begin{aligned}
& \mathrm{W}(\mathrm{x}, \mathrm{t})+\frac{p(z, t-x+z)}{p(x, t)} P V\left[Y_{l}(x, a, t)\right]=P V[C(x, a, t)] \\
& \mathrm{W}(\mathrm{x}, \mathrm{t})=\left(\frac{p(x-1, t-1)}{p(x, t)}\right)\left[\left(\mathrm{e}^{\mathrm{r}} \mathrm{W}(\mathrm{x}-1, \mathrm{t}-1)\right)+\left(\mathrm{e}^{\mathrm{r} / 2}\left[\left(\frac{p(z, t-x+z-1) Y_{l}(x-1,0, t-1)}{p(x-1, t-1)}\right)-C(x-1,0, t-1)\right]\right)\right]
\end{aligned}
$$

Note that the expectations in expected household size (measured in adult equivalent consumer units) and expected household labor income must both be adjusted by $p(z, t-x+z) / p(x, t)$ to reflect survival to age $x$. $W(x, t)$ measures wealth and is defined so that cohort wealth is maintained. That is, there are lateral not vertical bequests - wealth saved by last year's households aged $x-1$ is shared among this year's surviving heads aged $x$. 


\section{Life Cycle Optimization:}

Define the instantaneous household utility function to be:

$$
\begin{aligned}
& u\left[C(x, a, t),\left(\frac{p(z, t-x+z)}{p(x, t)}\right) H(x, a, t)\right]= \\
& \left(\frac{p(z, t-x+z)}{p(x, t)}\right) H(x, a, t)\left(\left[\left(\frac{\left[\left(\frac{p(z, t-x+z)}{p(x, t)}\right) H(x, a, t)\right.}{\left(\frac{C(x, a, t)}{2}\right)}-1\right) / 1-\gamma\right) /\right.
\end{aligned}
$$

Although this household utility function appears to be complex, its derivative is simple:

$$
\frac{\partial u}{\partial C(x, a, t)}=\left[\frac{C(x, a, t)}{H(x, a, t)}\right]^{-\gamma}=\left[\frac{H(x, a, t)}{C(x, a, t)}\right]^{\gamma}
$$

The optimal household consumption path over the life cycle is derived below, after forming the Lagrangian and differentiating.

$$
\begin{aligned}
& \mathrm{L}=V-\lambda\left(W(x, t)+\frac{p(z, t-x+z)}{p(x, t)} P V\left[Y_{l}(x, a, t)\right]-P V[C(x, a, t)]\right) \\
& \partial L / \partial C(x, a, t)=e^{-p a}\left[\frac{H(x, a, t)}{C(x, a, t)}\right]^{\gamma}-\lambda e^{-r a}=0 \\
& C(x, a, t)=H(x, a, t) e^{(r-\rho) a / \gamma} \lambda^{-1 / \gamma}
\end{aligned}
$$

Substituting $C(x, a, t)$ into the budget constraint yields:

$$
\lambda^{-1 / \gamma}=\frac{\left(W(x, t)+\left(\frac{p(z, t-x+z)}{p(x, t)}\right) P V\left[Y_{l}(x, a, t)\right]\right)}{\int_{0}^{\omega-x} e^{-r a} H(x, a, t) e^{(r-\rho) a / \gamma} d x}
$$

Substituting back for $\mathrm{e}^{-1 / \tilde{a}}$ yields the expression for consumption $a$ years in the future as assessed at current age $x$.

$$
\begin{aligned}
& C(x, a, t)= \\
& \frac{\left(W(x, t)+\left(\frac{p(z, t-x+z)}{p(x, t)}\right) P V\left[Y_{l}(x, a, t)\right] H(x, a, t) e^{(r-\rho) a / \gamma}\right.}{\int_{0}^{\omega-x} e^{-r a} H(x, a, t) e^{(r-\rho) a / \gamma} d a}
\end{aligned}
$$




\section{Appendix C. Data and Calculation Related Details of the Simulations}

\section{Earnings}

Earnings by age and sex are available from 1976 to 1993. These give total labor earnings, including selfemployment earnings, per member of the population in each age-sex group. These were averaged across sex for each year. A standard age profile of earnings was calculated as the exponentiated average over time of the logs of earnings at each age. Evidently this standard age schedule abstracts from changes over time in the earnings of children and in the labor force participation of men and women, but examination of the data suggests that this is not a major issue.

The standard age profile formed in this way was then used to calculate a measure of household labor supply for each age of head, by using it to weight the average age composition of the household at each age of head. Actual household earnings in any given year are then found by multiplying this measure by the level of earnings in that year.

The earnings level variable was constructed by calculating the actual total labor earnings each year, by combining the population age distribution with the actual age-earnings profile for each year, and then dividing this total by the standard labor supply measure, formed by combining the population age distribution with the standard earnings age schedule described above. The resulting earnings level measure reflects both productivity growth and changes in participation rates over time. Its growth rate slightly exceeds that of productivity over this period, as would be expected due to rising female labor force participation. Note that for this reason, this empirical implementation of $w(t)$ does not correspond exactly to the variable as defined earlier.

Households are assumed to calculate their expected future earnings by forming the measure of household labor supply for all future periods in the manner described above, based on the standard age schedule of earnings. They then multiply this by the projected future level of earnings for each period to form their estimate of household earnings in future years, which they then discount back to the present at an appropriate rate.

\section{Support Ratio}

Calculation of the support ratio requires weights to use for earnings and weights to use for consumption. For earnings, the standard age schedule of earnings described above is used. For consumption, calculation of weights is much more complicated. Micro-level data on household total expenditure and household composition are used. Within each household, Deaton weights (see Deaton and Muelbauer, 1986) are used to allocate consumption to household members of each age. Then for a given age, consumption is averaged across all of these allocated amounts. In this way, the consumption weights reflect not only the Deaton weights, but also expenditure level of households with the age of head with whom they typically reside. For example, children will tend to reside with younger aged heads, and therefore to have a share of lower consumption levels. 


\section{Expectation Formation}

We assume that adults form an expectation of a current underlying rate of interest or of earnings growth by taking a five-year unweighted average of the most recent observations. However, they do not necessarily believe that the current underlying rates will persist over the long run. Instead, they project that current rates will slowly converge to an ultimate value, which may be chosen based on the experience of other developed countries, for example. Each future year, the gap between the projected level and the ultimate level is assumed to shrink by 10 percent. This assumption leads to the following specification for the future rates of change and future levels of interest or earnings. The expectation in year $t$ of the underlying rate of interest is:

The expectation for $t+a$ years in the future (for all a $>0$ ) converges to a long run, ultimate rate of $r^{*} e$.

$$
\begin{gathered}
r_{e}(t, 0)=\sum_{e}^{t} r(b) / 5 \\
r_{e}(t, a)=r_{e}^{*}+0.9\left[r_{e}^{* * t-4}-r_{e}(t, a-1)\right]
\end{gathered}
$$




\section{REFERENCES}

Adams, N. (1971) "Dependency rates and savings rates: comment: American Economic Review 61: 472475.

Auerbach, A. and L. Kotlikoff (1987) Dynamic Fiscal Policy (Cambridge University Press).

*Attanasio, Orazio and Guglielmo Weber (1995) "Is Consumption Growth Consistent with Intertemporal Optimization? Evidence from the Consumer Expenditure Survey" Journal of Political Economy v.103 n.6 pp.1121-1157.

Bilsborrow, R.E. (1979) "Age distribution and savings rates in less developed countries" Economic Development and Cultural Change 28: 23-45.

Bilsborrow, R.E. (1980) "Dependency rates and aggregate savings rates revisited: corrections, further analysis, and recommendations for the future" in J.L. Simon, and J. DaVanzo, eds., Research in Population Economics 2 (Greenwich, Conn.: JAI Press) 183-204.

Carroll, Christopher D. and Lawrence H. Summers (1991) "Consumption Growth Parallels Income Growth: Some New Evidence," in Bernheim, B. Douglas and John B. Shoven, eds., National Saving and Economic Performance, A National Bureau of Economic Research Project Report (Chicago: The University of Chicago Press) 305-343.

Coale, Ansley and Hoover (1958). "Population Growth and Economic Development in Low-income Countries: A Case Study of India." Princeton: Princeton University Press.

Collins, Susan. M (1991) "Savings Behavior in Ten Developing Countries," in Bernheim, B. Douglas and John B. Shoven, eds., National Saving and Economic Performance, A National Bureau of Economic Research Project Report (Chicago: The University of Chicago Press) 349-372.

*Conroy, Michael E. (1979) "Population Growth, Life-cycle Saving, and International Differences in Steady-state Optimal Saving Rates. Demography v. 16, n. 3, pp. 425-438.

Cutler, DM, JM Poterba, LM Sheiner, and LH Summers (1990). "An Aging Society: Opportunity or Challenge?” Brookings Papers on Economic Activity (1).

Deaton, Angus (1989) "Saving in Developing Countries: Theory and Review," Proceedings of the World Bank Annual Conference on Development Economics, Supplement to the World Bank Economic Review and the World Bank Research Observer, 61-96.

Deaton, Angus (1991) "Saving and Liquidity Constraints," Econometrica 59, 5 (September) 1221-1248.

Deaton, Angus and John Muelbauer (1986) "On Measuring Child Costs: With Applications to Poor Countries," Journal of Political Economy v.94, n.4 pp.720-744

Deaton, Angus and Christina Paxson (1994) "Saving, Growth and Aging in Taiwan" in David Wise, ed., Studies in the Economics of Aging (University of Chicago Press, Chicago), pp.331-364.

Deaton, Angus and Christina Paxson (1997) "The Effects of Economic and Population Growth on National Saving and Inequality." Demography 34(1): 97-114. 
Dekle, Robert, and Lawrence Summers (1991) "Japan's High Saving Rate Reaffirmed," Bank of Japan Monetary and Economic Studies 9(2) (September) 63-78.

Edwards, Sebastian (1995) "Why are Latin America's Saving Rates so Low? An International Comparative Analysis" mimeo.

Feeney, Griffith and Andrew Mason (1997) "Population in East Asia" Conference on Population and the Asian Economic Miracle, East-West Center, Honolulu, January.

Feldstein, Martin S. (1974) "Social Security, Induced Retirement, and Aggregate Capital Formation." Journal of Political Economy 82 (5): 905-927.

Friedman, Milton (1957) A Theory of the Consumption Function (Princeton, N.J.: Princeton University Press).

Fry, Maxwell J. (1978) "Money and Capital or Financial Deepening in Economic Development?" Journal of Money, Credit and Banking 10(4) 464-75.

Fry, Maxwell J. and Andrew Mason (1982) "The variable rate of growth effect in the life cycle saving model," Economic Enquiry 20 (July) 426-442.

Giovannini, A. (1985) "Saving and the Real Interest Rate in LDCs" Journal of Development Economics (18) $197-217$.

Goldberger, A. (1973) "Dependency rates and savings rates: comment" American Economic Review 62: 232-233.

*Graham, John W. (1987) "International Differences in Saving Rates and the Life Cycle Hypothesis," European Economic Review 31: 1509-1529.

Gupta, K.L. (1971) "Dependency Rates and savings rates: comment" American Economic Review 61: 496-671.

Gupta, K.L. (1984) Finance and Economic Growth in Developing Countries (London: Croom Helm).

Gupta, K.L. (1987) "Aggregate Savings, Financial Intermediation, and the Interest Rate" Review of Economics and Statistics (69) 303-11.

*Hammer, J. (1986) "Population Growth and Savings in LDCs: A Survey Article" World Development (14) $579-591$.

Harrigan, Frank (1996) "Asian Saving: Theory, Evidence and Policy," mimeo (August).

Hayashi, Fumio (1986) "Why is Japan's Saving Rate so Apparently High?" in Stanley Fischer, ed., NBER Macroeconomics Annual 19861 (Cambridge: MIT Press) 147-210.

Horioka, Charles Yuji (1993) "Is Japan's Household Saving Rate Really High?" ISER Discussion Paper No. 308, Institute of Social and Economic Research, Osaka University, (September). 
Kang, Kenneth H. (1994) "Why did Koreans Save so 'Little' and why do they now save so 'Much"' International Economic Journal 8 (Winter) 99-111.

Kelley, Allen C. (1988) "Population Pressures, Saving, and Investment in the Third World: Some Puzzles," Economic Development and Cultural Change 36, 3 (April) 449-464.

Kelley, Allen C. and R.M. Schmidt (1996) "Saving, Dependency and Development" Journal of Population Economics v.9 n.4, pp.365-386..

Kim, J.-I,, and L.J. Lau (1995) "The Role of Human Capital in Economic Growth of the East Asian Newly Industrialised Countries," Asia-Pacific Economic Review 1, 3-22. .

John Knodel, Aphichat Chamratrithirong and Nibhon Debavalya, "Societal Change and the Demand for Children," and "Synthesis and Conclusions: Toward an Understanding of Thailand's Rapid Fertility Decline," Chapter 7 and 10 of Thailand's Reproductive Revolution (University of Wisconsin Press, 1987), pp.117-154 and 193-205.

Kotlikoff, Laurence J. and Lawrence H. Summers (1981) "The Role of Intergenerational Transfers in Aggregate Capital Accumulation", Journal of Political Economy v.89, pp.706-732.

*Lahiri, Ashok K. (1989) "Dynamics of Asian Savings: The Role of Growth and Age Structure," Staff Papers, International Monetary Fund (Washington).

Lazear, Edward P. and Robert T. Michael (1988) Allocation of Income Within the Household (University of Chicago Press, Chicago and London).

Lee, Ronald D. (1994) "The Formal Demography of Population Aging, Transfers, and the Economic Life Cycle," in Linda Martin and Samuel Preston, eds.; The Demography of Aging (National Academy Press, 1994) pp.8-49.

Lee, Ronald D. (1996). "Intergenerational Transfers and the Economic Life Cycle: A Cross-cultural Perspective," Conference on Intergenerational Economic Relations, IUSSP and East-West Center, Honolulu, September.

Leff, Nathaniel H. (1969) "Dependency rates and savings rates," American Economic Review 59 (December 1969) 886-895.

Leff, Nathaniel H. (1980) "Dependency Rates and Savings Rates: A New Look," in Julian Simon, ed., Research in Population Economics 2 (Greenwich, Conn.: JAI Press) 205-214.

Leff, Nathaniel H. (1984) "Dependency Rates and Savings Rates: Another Look," The American Economic Review 74 (March) 231-233.

Mankiw, N. Gregory, David Romer, and David N. Weil (1992) "A Contribution to the Empirics of Economic Growth," Quarterly Journal of Economics (May) 107(2) 407-438.

Mason, Andrew (1981) "An Extension of the Life-cycle Model and its Application to Population Growth and Aggregate Saving," East-West Population Institute Working Papers 4 (January). 
Mason, Andrew (1987) "National Saving Rates and Population Growth: A New Model and New Evidence," in D. Gale Johnson and Ronald D. Lee, eds., Population Growth and Economic Development: Issues and Evidence, (Madison: University of Wisconsin Press) 523-560.

Mason, Andrew (1988) "Saving, Economic Growth, and Demographic Change," Population and Development Review 14 (March) 113-144.

Masson, P., Bayoumi. T., and Samiei, H (1995) International Evidence on the Determinants of Private Saving, International Monetary Fund, Working Paper WP/95/51.

McKinnon, R.I. (1973) Money and Capital in Economic Development (Washington, DC: The Brooking Institute).

Modigliani, Franco (1966) "The life cycle hypothesis of savings, the demand for wealth and the supply of capital," Social Research (Summer) 160-217.

Modigliani, Franco (1988) "The Role of Intergenerational Transfers and Life Cycle Saving in the Accumulation of Wealth," Journal of Economic Perspectives 2, 2 (Spring) 15-40.

*Modigliani, Franco and Albert Ando (1957) "Test of the Life Cycle Hypothesis of Saving," Bulletin of the Oxford University Institute of Statistics 19 (May) 99-124.

Modigliani, Franco and Richard Brumberg (1954) "Utility Analysis and the Consumption Function: An Interpretation of Cross-section Data," in K. Kurihara, ed. Post-Keynesian Economics (Princeton University Press).

National Research Council (1986). "Population Growth and Economic Development: Policy Questions." Washington, DC: National Academy Press.

Ogaki, Masao, Jonathan Ostry and Carmen Reinhart (1996) "Saving Behavior in Low-and MiddleIncome Developing Countries: A Comparison" International Monetary Fund Staff Papers, v.43 n.1 (March).

Ram, Rati (1982) "Dependency Rates and Aggregate Savings: A New International Cross-Section Study," American Economic Review 72 (June) 537-544.

Ram, Rati (1984) "Dependency Rates and Savings: Reply," American Economic Review 74 (March) 234-237.

*Rossi, Nicola (1989) "Dependency Rates and Private Savings Behavior in Developing Countries," Staff Papers International Monetary Fund (Washington) 36 (March) 166-81.

Schmidt-Hebbel, Klaus, Luis Serven, and Andres Solimano (1996) "Saving and Investment: Paradigms, Puzzles, Policies," The World Bank Research Observer 11(1) (February) 87-118.

Shaw, E (1973) Financial Deepening in Economic Development (New York: Oxford University Press).

*Shumaker, Linda D. and Robert L. Clark (1992) "Population Dependency Rates and Savings Rates: Stability of Estimates," Economic Development and Cultural Change, 40, 2 (January) 319-332. 
Summers, Robert and Alan Heston (1991) “The Penn World Table (Mark 5): An Expanded Set of International Comparisons, 1950-1988" Quarterly Journal of Economics 327-366.

Taiwan Department of Statistics, The Ministry of the Interior (1993) Statistical Abstract of Interior of the Republic of China.

Tobin, James (1967) "Life cycle saving and balanced economic growth," in William Fellner, ed., Ten Economic Studies in the Tradition of Irving Fisher (New York: Wiley Press) 231-256.

*Webb, Steven B. and Heidi S. Zia (1989) "The Effect of Demographic Changes on Saving for LifeCycle Motives in Developing Countries," Policy, Planning, and Research Working Papers, The World Bank, July.

Williamson, Jeffrey (1979) "Why do Koreans Save 'So Little'?” Journal of Development Economics 6, pp 343-62.

Williamson, Jeffrey and Matthew Higgins (1997) "The Accumulation and Demography Connection in East Asia." Conference on Population and the Asian Economic Miracle. East-West Center, Honolulu, Hawaii, January 7-10.

*Willis, Robert (1988) "Life Cycles, Institutions and Population Growth: A Theory of the Equilibrium Interest Rate in an Overlapping-generations Model," in Ronald Lee, W. Brian Arthur and Gerry Rodgers eds., Economics of Changing Age Distributions in Developed Countries (Oxford University Press), pp.106-138.

World Bank (1984) World Development Report 1984 (New York: Oxford University Press).

World Bank (1995) ) World Development Report 1995 (New York: Oxford University Press).

* This bibliographic entry is not cited in the main text. 